\title{
ANADOLU SELÇUKLU MEDRESELERI VE DARÜŞŞİFALARINDA TÜRBE
}

\section{NERMIN ŞAMAN DOĞAN*}

\section{Giriş}

Bu çalışmada öncelikle Anadolu Selçuklu medrese ve darüş̧ifalarında yer alan türbeler bani, tarih, konum, plan ve mimari özellikleri açısından ele alınmıştır. Özellikle günümüze ulaşan az /sınırlı sayıda darüşşifa örneği olduğu için Selçuklu devletine tâbi eş zamanlı kurulan Mengücekli Beyliği’nin bir yapısına da yer verilmiştir. Selçuklu döneminde yeni fethedilen şehirlerde askeri, dini ve sosyal işlevli yapılar inşa edilerek kentlerin değişimi ve gelişimi hızlandırılmıştır. $\mathrm{Bu}$ kentlerde eğitim ve sağllk yapılarının varlığı, çeşitliliği ve çokluğu yerleşimin gelişmişlik düzeyi ve kültürel ortamının zenginliğini ortaya koymaktadır. Şehir içinde bulunan eğitim ve sağlık yapıları/medreseler-darüşsifalar işlevleri ve plan tasarımları açısından ortak özellikler yansıtmaktadır. Birbirine bitişik "medresedarüşşifa", "cami-darüsssiffa", "cami-medrese" örnekleri olduğu gibi bağımsız inşa edilen medrese ve darüşsifalar da bulunmaktadır. Bu bağlamda türbelerin yapılardaki konumu, avlu çevresindeki diğer mekânlar ya da çevresiyle ilişkileri bütüncül bir yaklaşımla değerlendirilmiştir.

Selçuklu medrese ve darüşşifaları çoğunlukla açı ya da kapalı avlulu plan şeması yansıtmaktadır. Medreselerdeki mekânsal dağılım incelendiğinde genellikle dikdörtgen, bazı örneklerde kare ya da kareye yakın dikdörtgen planlı açı ya da kapalı avluların çevresine dizilen sayıları bir-dört arasında değişen revak sıraları ve eyvanlar, öğrenci odaları, kışlık-yazlık dershane odaları ile imaret, kütüphane, mescit ve türbe gibi farklı işlevli birimler yer alır .

* Prof. Dr., Hacettepe Üniversitesi, Edebiyat Fakültesi, Sanat Tarih Bölümü, Ankara/TÜRKIYYE, nerminsd@gmail.com

1 Abdullah Kuran, Anadolu Medreseleri 1, Orta Doğu Teknik Üniversitesi, Mimarlık Fakültesi Yayınları, Ankara 1969; Yekta Demiralp, Erken Dönem Osmanl Medreseleri (1300-1500), Kültür Bakanlığı Yayınları, Ankara 1999, s. 202-230; Yekta Demiralp, "Osmanlı Öncesi Anadolu Medreselerinde Örtü ve Erken Osmanlı Medreseleri ile Karşılaştırma”, Sanat Tarihi Dergisi, XV/2 (2006), ss. 29-48. 
Selçuklu döneminde banilerin kendi yaptırdıkları medrese ya da darüşşifa içindeki türbeye gömülmeleri bir gelenek olmuştur ${ }^{2}$. Çoğunlukla medrese ve darüşşifalarda avlunun yatay ve dikey eksenlerinde bulunan eyvanlardan (giriş, ana ve yan eyvanlar) birine bitişik kare planlı ve üzeri kubbe ile örtülü mekânlar türbe olarak tasarlanmıştır. Az sayıdaki örnekte eyvan türbeye dönüştürülmüş ya da türbe yapının cephelerinden birine bitişik yapılmıştır. Yapılarda eyvan sayısı türbenin yerinin belirlenmesinde etkilidir. Medreselerde türbenin içten ve dıştan bitişik yapıldı̆̆ı eyvanların özel seçildiği, türbe algısına özen gösterildiği anlaşılmaktadır. Bu çerçevede yapıların içinde ya da dışında yer alan türbelere medreselerin içinden girişin sağlanması ortak özelliklerdir. Selçuklu medreseleri ve darüşşifalarında çoğunlukla dikdörtgen planlı öğrenci odaları ve eyvanların üzeri sivri tonoz, ana eyvanın bitişiğindeki kışlık dershane odaları, mescit, türbe, kütüphane ve imaret gibi kare planlı özel işlevli mekânların üzeri kubbe ile örtülerek, bu birimlerin içten ve dıştan vurgulanması amaçlanmıştır.

Bu çalışmada Anadolu Selçuklu dönemi medreseleri ve darüşşifalarının içinde ya da dıştan bitişiğinde yer alan türbelerin tarihi, banisi, konumu, mimari özellikleri ve çevresiyle olan ilişkileri dikkate alınarak, konunun önemi vurgulanacaktır. Anadolu Türk mimarisinde türbeler üzerine çalışan araştırmacılardan O. Arık, O. C. Tuncer ve H. Önkal'ın yapıların kataloğunu içeren yayınları monografik çalışmalardır. İlk iki yayında üzerinde çalıştığımız konuyla ilişkin verilen bilgiler sınırlıdır. Özellikle H. Önkal'ın Selçuklu türbelerini konu alan kitabı, bu anlamda çalışmamızı yönlendiren ve gelişmesine katkı sağlayan birincil kaynak olmuştur ${ }^{3}$.

Anadolu Selçuklu döneminde çoğunlukla sultanların/hükümdarlarının yaptırdığı kervansaraylar şehir dışındaki, Selçuklu ve İlhanlı devlet adamlarının (vezirlerin, lalaların vb.) inşa ettirdiŭi medrese ve darüşşifalar şehir içindeki anıtsal yapıları oluşturmaktadır. Sultanlar/hükümdarlar uluslararası ticaret yolları üzerindeki kervansarayları, devlet adamları kent içindeki yönetici kadrosunu yetiştiren anıtsal medreseleri yaptırarak, güçlerini göstermekte, prestijlerini artırmaktadır.

Bu araştırmada medrese-darüşşifa kütlesi içinde ve medrese kütlesi dışında yer alan türbeler iki ana başlıkta incelenmiştir. Medrese ve darüşşifa kütlesi içinde olan

Kuran, Medreseler, ss. 138-140; Demiralp, Osmanh Medreseleri, ss. 226-228; Demiralp, "Medreselerde Örtï...", ss. 38-39.

M. Oluş Arık, "Erken Devir Anadolu-Türk Mimarisinde Türbe Biçimleri, Anadolu (Anatolia), 11(1967), ss. 57-100; O. C. Tuncer, Anadolu Kümbetteri-1-Selçuklu Dönemi, Güven Matbaası, Ankara 1986; H. Önkal, Anadolu Selçuklu Türbeleri, Atatürk Kültür Merkezi Yayınları, Ankara 1996. 
örnekler giriş, yan, ana eyvana bitişik türbeler ve eyvanın türbeye dönüştürüldüğü örnek olarak dört alt başlıkta ele alınmıştır. Medrese kütlesi dışında olan türbeler ise ana eyvanın arka cephesine/dikey eksenine bitişik ve cephelerden birine bitişik türbeler olarak iki alt başlıkta sunulmuştur. Çalışmada incelenen medreselerin planları ile bazı örneklerin fotoğraflarına yer verilmiştir.

\section{A. Medrese ve Darüşşifa Kütlesi İçinde Olan Türbeler}

\section{Giriş Eyvanına Bitişik Türbeler}

Selçuklu yapılarından Konya'daki Sırçalı/Muslihiye (1242), Kayseri Avgunu (13. yüzyılın ort.) ve Sivas Buruciye (1271) medreselerinde giriş eyvanının bitişiğindeki kare planlı mekânlar türbe olarak tasarlanmıştır (Plan 1a-c). Sırçalı Medrese doğu cephesindeki taç kapısı üzerinde bulunan kitabesine göre 1242 yılında Lala Bedreddin Muslih, Sivas Buruciye Medresesi batı cephesindeki taç kapısı üzerinde yer alan kitabesine göre 1271 yılında Muzafferüddin Burucirdi tarafindan inşa edilmiştir. Avgunu medresesinin kesin tarihi ve banisi bilinmemektedir ${ }^{4}$. Bu medreselerde eyvan-türbe ilişkisi, medresenin ve türbenin tek ya da çift katlı oluşu, mimari ögeleri ve dışa yansıması farklı çözümlenmiştir.

Konya Sırçalı Medrese açık avlulu, iki eyvanlı ve iki katlı, Kayseri Avgunu Medresesi açık avlulu, iki eyvanlı ve tek katlı bir yapıdır. Sırçalı Medrese'de avlunun doğusundaki giriş eyvanının kuzeyinde, Avgunu Medresesi'nde avlunun kuzeyindeki giriş eyvanının batısında bulunan iki katlı türbelere eyvandan giriş sağlanmaktadır (Planla). Medreselerde türbelerin konumu, iki katlı oluşu ve organik ilişkileri ortak özelliklerdir (Fotoğraf 1-2). Sırçalı örneğinde türbenin kare planlı ve haç tonoz örtülü alt/mezar odası, kare planlı ve çapraz tonoz örtülü üst katı/ziyaret odası dışa yansımazken, Avgunu Türbesi’nde kare planlı ve sivri tonoz örtülü alt, içten ve dıştan sekizgen planlı, içten kubbe, dıştan sekizgen piramidal külahla örtülü ziyaret odası (kaide, gövde, külah) dışa yansımaktadır5. Avgunu

Medreseler için bkz, Mahmut Akok, "Konya'da Sırçalı Medresenin Rölöve ve Mimarisi”, Türk Arkeoloji Dergisi, 18/1, (1969). ss. 5-35; Kuran, Medreseler, ss. 67-69, 74-75, 90-92; Metin Sözen, Anadolu Medreseleri Selçuklu ve Beylikler Devri, I, Açık Medreseler, İstanbul Teknik Üniversitesi Mimarlık Fakültesi Yayınları, İstanbul 1970, ss. 18-21, 49-57, 160-165; Orhan Cezmi Tuncer, Anadolu Selçuklu Mimarisi ve Moğollar, (Yayınevi belirsiz), Ankara 1986, ss. 19-22; Burhan Bilget, Sivas'ta Buruciye Medresesi, Kültür Bakanlığı Yayınları, Ankara 1991; Yaşar Erdemir, Sirçalı Medrese Mezar Anttlan Müzesi, 3. bs., Konya Valiliği İl Kültür ve Turizm Müdürlüğü Yayınları, Konya 2015.

5 Orhan Cezmi Tuncer, Anadolu Kümbetleri I Selçuklu Dönemi, Güven Matbaası, Ankara 1986, ss. 138140; Hakkı Önkal, Anadolu Selçuklu Türbeleri, Atatürk Kültür Merkezi Yayınları, Ankara 1996, ss. 391-393; Erdemir, Sirçalı, ss. 91-95. 
örneğinde kare prizmal kaidenin köşelerde üçgen biçiminde pahlanmasıyla sekizgen gövdeye dönüştüğü, doğu, güneydoğu ve güney cepheleri medreseye bitişik, diğer beş cephesinde ise üst seviyede dikdörtgen pencerelerin bulunduğu görülmektedir. Sırçalı Medrese Türbesi’nin toprak altında olan alt katına/ mezar odasına eyvanın kuzey duvarının eksenindeki merdivenle inilmektedir ${ }^{6}$. Türbenin ziyaret odasında alt seviyede bulunan batı duvardaki pencere avluya, doğu duvardaki pencere ise dışa açılmaktadır. Avgunu Medresesi'nde hem giriş eyvanının batısına bitişik, hem de kuzeybatı köşede konumlanan türbe, doğrudan dışarıyla bağlantılıdır (Plan 1b). Sırçalı Medrese'de ise giriş eyvanının kuzeyi ile kuzeydoğu köşe odasına bitişik olan, bir başka deyişle ara mekânda yer alan türbe dıştan algılanamamaktadır. Sırçalı Türbesi’nde çini kaplı üç sanduka ile Avgunu Türbesi’nin alt katında yığma moloz taşlarla oluşturulmuş iki mezar bulunmaktadır ${ }^{7}$. Sırçalı örneğinde sandukalardan biri bani Bedreddin Muslih'e, diğerleri ailesine ait olmalıdır ${ }^{8}$. Sırçalı ve Avgunu türbelerinde düzgün kesme taş kullanılmıştır. Sırçalı/Muslihiye Türbesi’nin üst kat/ziyaret odası firuze ve patlıcan moru renkli sırlı ve sırsız tuğlalarla örülmüş çapraz tonozla örtülmüştür. Sırçalı Medrese'nin avlu çevresindeki birimler (revaklar, giriş ve ana eyvan duvarları ve tonozları) ile türbenin tonozunda sırlı-sırsız tuğla, sandukalarında çini mozaik tekniğinin uygulandığı görülür. Yapının ana eyvan kemerinde yer alan kitabede adı geçen Tuslu Mehmed'in türbenin çinilerini de programladığı anlaşılmaktadır ${ }^{9}$.

Sırçalı Medrese'nin banisi Selçuklu Sultanı II. Alaeddin Keykubad'ın Lalası Bedreddin Muslih'dir ${ }^{10}$. Avgunu Medresesi'nin banisi bilinmemektedir.

Sivas Buruciye Medresesi açık avlulu, dört eyvanlı ve tek katlı bir yapıdır. Medresede giriş eyvanının kuzeyine türbe, güneyine mescidin bitişik yapılması ile

Akok, "Sirçal....", ss. 11-12.

Şerare Yetkin, Anadolu'da Türk Çini Sanatmn Gelişmesi, İstanbul Üniversitesi Edebiyat Fakültesi Yayınları, İstanbul 1986, 2. bs., s. 52; Tuncer, Kümbetter I, ss. 138-140; Önkal, a.g.e., ss. 391-393; Erdemir, Sirçal, ss. 91-95.

8 Erdemir, Sirçall, ss. 93-94.

9 Michael Meinecke, "Tuslu Mimar Osman Oğlu Mehmed Oğlu Mehmed ve Konya'da 13. Üncü Yüzyllda Bir Çini Atölyesi”, Türk Etnoğrafya Dergisi, 11 (1968), ss. 81-93; Yetkin, a.g.e., s. 52; Ömür Bakırer, Selçuklu Öncesi ve Selçuklu Dönemi Anadolu Mimarisinde Tuğla Kullanım, I, Orta Doğu Teknik Üniversitesi Yayınları, Ankara 1981, ss. 384-388; Zafer Bayburtluoğlu, Anadolu'da Selçuklu Dönemi Yapı Sanatçılan, Erzurum Atatürk Üniversitesi Yayınları, Erzurum, 1993, ss. 224-228; Zeki Sönmez, Başlangzcondan 16. Yüzylla Kadar Anadolu Türk-İslam Mimarisinde Sanatçlar, 2.bs., Türk Tarih Kurumu Yayınları, Ankara 1995, ss. 257-262; Oluş Arık, "Anadolu Selçuklu Toplum Hayatında Çini”. Anadolu'da Türk Devri Çini ve Seramik Sanatı, Ed. Gönül Öney ve Zehra Çobanlı, Kültür ve Turizm Bakanlığı Yayınları, İstanbul 2007, s. 44.

10 İbn Bibi, a.ge.., II. Cilt, ss. 136-154; Turan, Selçuklular Zamannda Türkiye, ss. 491-492, 509. 
avlunun batı-ön kanadı özel/farklı işlevli birimlere ayrılmıştır (Plan 1c). Medresede mescit-türbe gibi kare planlı ve kubbe ile örtülü birimlerin ön kanatta akılcı dizilimi yapım aşamasında tasarlandıklarını göstermektedir. Medresede giriş eyvanının kuzeyine bitişik tek katlı türbeye avludan girişin sağlanması Sırçalı ve Avgunu örneklerinden farklıdır ${ }^{11}$. Burucirdi Türbesi kare planlı, üçgen kuşakla geçilen kubbe ile örtülü, bir kapıyla avluya, büyük boyutlu bir pencere ile dişa açılmaktadır. Batı cephe/ön yüzde taç kapının simetriğinde bulunan kademeli bordürlerle kuşatılan altı sıra mukarnas kavsaralı dikdörtgen pencerelerden kuzeydeki türbeye, güneydeki mescide açılmaktadır. Türbenin güney duvarı ekseninde tahrip olmuş bir mihrap nişi ile çini kaplamaları dökülmüş, harçla sıvanmış üç sanduka yer alır $^{12}$. Türbenin düzgün kesme taş ile örülen duvarları firuze renkli altıgen çinilerle kaplanarak, kubbeye geçiş ve kubbesinde firuze, patlıcan moru sırlı-sırsız tuğlalar kullanılmıştır ${ }^{13}$. Türbenin duvarlarını üst seviyede firuze renkli çinilerle spiraller oluşturan kıvrık dal ve rumi motifleriyle bezeli zemin üzerine, patlıcan moru çiniler kullanılarak sülüsle yazılan tek satırlık kitabe şeridi sınırlamaktadır ${ }^{14}$. Batı duvardaki dualar içeren kitabe şeridinde "...Bu zaynf, garip, yalnız kul olan Muzaffer b. Hibetullah el-Mufaddali el-Burucerdi türbesidir..." yazılıdır ${ }^{15}$.

Sivas Buruciye Türbesi bani adını veren kitabesi, özellikle duvarları, kubbe ve kubbeye geçişlerde yer alan çini mozaik tekniği ile sırl--sırsız tuğla örgülü yoğun bezemeleri mekâna verilen önemi göstermektedir. Medresede avluyu kuşatan birimler arasında bani Muzafferüddin Burucirdi Türbesi, büyük boyutlu ve mukarnas kavsaralı penceresi ile dıştan/ön cepheden, yoğun çini süsleme programı ile içten vurgulanmıştır.

İncelenen üç medresede giriş eyvanına bitişik türbe kurgusu ortak olsa da uygulamada bazı farklılıklar gözlenmektedir. Üstelik Kayseri Avgunu Medresesi Türbesi giriş eyvanından girilen, dönemin bağımsız türbeleri gibi dıştan planı, cepheleri, örtüsü/külahı okunabilen kurgusuyla farklıdır. Bu medreselerde türbelerin giriş eyvanı ile aynı düzlemde bulunması, pencereleri ya da üç boyutlu görünümleri ile ön cepheye yansımaları dikkat çekicidir.

1 Kuran, Medreseler, ss. 90-92; Sözen, Anadolu Medreseleri, I, ss. 49-57; Bilget, Sivas Buruciye, ss. 22-31

2 Bilget, Sivas Buruciye, ss. 30-31; Arık, “Anadolu Selçuklu Toplum Hayatında Çini”, ss. 61-62.

3 Bakırer, Selçuklu Dönemi Tuğla, I, ss. 444-447; Arık, "Anadolu Selçuklu Toplum Hayatında Çini”, ss. 61-62.

14 Yetkin, a.g.e., ss. 91-92; Bilget, Sivas Buruciye, ss. 22-31; Arık, "Anadolu Selçuklu Toplum Hayatrnda Çini”", ss. 61-62.

15 Yetkin, a.g.e., s. 92; Bilget, Sivas Buruciye, ss. 38-40. 


\section{Yan Eyvana Bitişik Türbeler}

Kayseri Gevher Nesibe (1205-1206), Akşehir Taş (1250) ve Kırşehir Caca Bey (1272) medreselerinde yan eyvanların bitişiğindeki mekânlar türbe olarak değerlendirilmiştir (Plan 2a-c). Kayseri Gevher Nesibe Darüşşifası-Medresesi taç kapısı üzerindeki kitabesine göre 602 H. / 1205-1206 M. yllında Selçuklu sultanı I. Gıyaseddin Keyhüsrev tarafindan kız kardeşi Gevher Nesibe'nin vasiyeti üzerine yaptırılmıştır. Akşehir Taş Medrese taç kapısı üzerindeki kitabesine göre 1250 yılında Emir-i Dad (adaletten sorumlu kişi) görevini üstlenen Selçuklu devlet adamı Sahip Ata Fahreddin Ali, Kırşehir Caca Bey Medresesi kitabesi ve vakfiyesine göre 1272 yllında Kırşehir Emiri Nureddin Caca Bey tarafindan inşa edilmiştir ${ }^{16}$.

Kayseri Çifte/Gevher Nesibe Darüş̧̧fası ve Medresesi birbirine bitişik (iki ayrı kütle), Gevher Nesibe Türbesi ise medresenin içinde yer alır (Plan 2a). Çifte/Gevher Nesibe Medresesi açık avlulu, dört eyvanlı ve tek kathı bir yapıdır. Medresenin avlusunda yatay eksendeki doğu eyvanın kuzeyine bitişik iki katlı türbe bulunur (Fotoğraf 3). Türbenin alt katı dikdörtgen planlı ve sivri tonoz örtülü, üst katı/ ziyaret odası dıştan kareye yakın dikdörtgen içten sekizgen planlı, içten kubbe, dıştan sekizgen piramidal külahla örtülüdür ${ }^{17}$. Medresenin avlusunda kuzeydoğuda bulunan iki revak birimi türbenin alt katı ile çift yönlü beş basamaklı merdivenle çıkılan ziyaret odasına açılmaktadır. Araştırmacılardan Başak İpekoğlu, bu örneği "Medresenin ve Darüsssifanm Birlikte İnşa Edildiğgi, Türbenin İlk Planlama Etabında Tasarlandığı Yapılar” olarak gruplamıştır ${ }^{18}$. Türbe, Selçuklu

16 Yapılar için bkz. Ferit M.-Mesut M. Selçuk Veziri Sahip Ata ile Oğullarmın Hayat ve Eserleri. Türkiye Matbaası, İstanbul 1934, ss. 87-91; Mahmut Akok, "Kayseri'de Gevher Nesibe Sultan Darüsssifası ve Sahabiye Medresesi Rölöve ve Mimarisi”, Türk Arkeoloji Dergisi, 17/1, (1968), ss. 133-184; Kuran, Medreseler, ss. 55-57, 65-67, 79-82; Sözen, Anadolu Medreseleri, I, ss. 22-28, 80-89; Metin Sözen, Anadolu Medreseleri Selçuklu ve Beylikler Devri, II, Kapal Medreseler, İstanbul Teknik Üniversitesi Mimarlık Fakültesi Yayıları, İstanbul 1972, s. 15-20; Mahmut Akok, "Konya-Akşehir'de Taş Medrese Binası ve Restorasyon Çalışmaları", Türk Etnoğrafya Dergisi, 26, (1977), ss. 5-26; Ahmet Temir, Kirşehir Emiri Caca Oğlu Nur El-Din’in 1272 Tarihli Arapça-Moğolca Vakfyesi, Türk Tarih Kurumu Yayınları, Ankara 1989; Gönül Cantay, Anadolu Selçuklu ve Osmanh Dariusşifalan, Atatürk Kültür Merkezi Yayınları, Ankara 1992, ss. 41-50; Arıkan, Nihat - Tuğutlu, Eylem-Eraslan, Yıldız, Kirşehir Emiri Caca Bey ve Medresesi "Simetrik Kaklaşımlar”, Kırşehir Valiliği Yayınları, Kırşehir 2009; Nermin Şaman Doğan, "Kayseri'deki Selçuklu Külliyeleri”, Hacettepe Üniversitesi Türkiyat Araştrmalan Dergisi, 16 (2012), ss. 191-214.

17 Akok, "Kayseri Gevher Nesibe...", ss. 138-139; Tuncer, Kümbetter I, ss. 142-146; Önkal, a.ge.e, ss. 379382; Nermin Şaman Doğan, "Kayseri'deki Selçuklu Dönemi Kadın Türbeleri”, Vakıflar Dergisi, 39 (2013), s. 16-18.

18 Başak İpekoğlu, "Birleşik İşlevli Yapılar", Anadolu Selçuklulan ve Beylikler Dönemi Uygarlhğ, 2, Ed. Ali Uzay Peker-Kenan Bilici, Kültür ve Turizm Bakanlığ̣ Yayınları, Ankara 2006, ss. 116-119. 
medreseleri içinde yer alan iki katlı ilk/erken tarihli örneklerden biridir ${ }^{19}$. Yapıda bugün sanduka bulunmamaktadır. Medresenin ön/güney ve doğu cephelerinden türbenin gövdesinin üst bölümü ile külahının dışa yansıtılarak görünür olmasına özen gösterilmiştir.

Akşehir Taş Medrese'de yatay eksendeki kuzey eyvanın batısına bitişik, Kırşehir Caca Bey Medresesi’nde doğu eyvanın kuzeyine bitişik ve kuzeydoğu köşe mekânını oluşturan kare planlı ve iki katlı türbe yer alır ${ }^{20}$.

Akşehir Taş Medrese açık avlulu, dört eyvanlı ve tek katlı bir yapıdır (Plan 2b). Medresede dışta batı cephenin kuzey köşesine mescit, içte avlunun kuzeyindeki yan eyvanın batısına bitişik kare planlı türbe ile mescidin ortak duvarla bağlanması, aynı yöndeki farklı işlevli birimleri vurgulamaktadır. Bu çerçevede medresenin batı/ön cephesinde eksenin kuzeyinde mescit ile güneyine bitişik türbenin yapılması akılcı bir çözümlemedir. Ayrıca medrese mescidinin kuzeybatı köşesindeki kübik kaideli, silindirik gövdeli ve iki şerefeli anıtsal minaresi de ön cepheye dâhil olmuştur.

Akşehir Taş Medrese Türbesi, kareye yakın dikdörtgen planlı ve sivri tonoz örtülü alt, kare planlı ve üzeri üçgen kuşakla geçilen kubbe ile örtülü üst kat/ ziyaret odasından oluşmaktadır. Alt kata/mezar odasına kuzeybatı köşedeki mescide bitişik eyvan kurgulu mekândan, ziyaret odasına medresenin avlusundan girilmektedir. Özgününde türbede yapının banisi Sahip Ata ailesine ait çiniyle kaplı üç sandukanın olduğu belirtilmektedir. Ayrıca türbenin duvarları, kubbeye geçiş ve kubbesinde tuğla ve çini kullanılmıştır ${ }^{21}$.

Kırşehir Caca Bey Medresesi kapalı avlulu, dört eyvanlı ve tek katlı bir yapıdır (Plan 2c). Medresede avlunun yatay eksenindeki doğu yan eyvanın kuzeyine bitişik, kuzeydoğu köşe mekânı türbe olarak yapılmıştır²2. Medresenin avlusuna hâkim olan dikey eksendeki/güneydeki ana eyvanın mescit olması (mescidi), dışta aynı yöndeki güney cephenin batısındaki kübik kaideli, silindirik gövdeli ve tek şerefeli minare ile de öne çıkarılmıştır. Benzer şekilde yatay eksendeki doğu yan eyvanın kuzeyine bitişik türbe ise kuzey cepheye eklemlenerek, anıtsal taç kapı ile

19 Şaman Doğan, “Kayseri Kadın Türbe...,", ss. 16-18.

20 Kuran, Medreseler, ss. 55-57, 79-82; Sözen, Anadolu Medreseleri, I, ss. 22-28; Sözen, Anadolu Medreseleri, II, ss.15-20; Tuncer, Kümbetler I, ss. 175-178; Önkal, a.g.e., ss. 404-408.

21 Ferit M.-Mesut M, a.g.e., ss. 89-90; Akok, “Akşehir Taş Medrese...”, ss. 7-8; Yetkin, a.g.e., ss. 59-60.

22 Kuran, Medreseler, ss. 55-57; Sözen, Anadolu Medreseler II, ss. 15-20; Tuncer, Kümbetler I, ss. 175-178; Önkal, a.g.e., ss. 404-408; Ahmet Şimşek, Cacabey ve Medresesi, Kırşehir Valiliği Yayınları, Kırşehir 2006, ss. 41-42; Arıkan-Tuğutlu-Eraslan, a.g.e., ss. 9-12. 
ön cepheyi hareketlendirmektedir. Türbe, kuzeydoğu köşedeki konumu ile hem medresenin içinde, hem de dişındadır. Türbenin kuzey/ön cepheye yansıması, anıtsal taç kapının doğusuna bitişik konumu, üç yönden mukarnas dizileriyle kuşatılmış beş sıra mukarnas kavsaralı dikdörtgen penceresi, kübik gövdesi, onikigen kasnak ve külahıyla ön cephe düzenlemesinin bir parçasıdır. Medresenin plan şeması ile ön cephe düzenlemesi medrese-türbenin eş zamanlı yapıldığını göstermektedir. Caca Bey Medresesi’nde taç kapı ve türbe ön/kuzey, mescit ve minaresi arka/güney cepheyi taçlandırmaktadır.

Kırşehir Caca Bey Türbesi kare planlı, içten üçgen kuşakla geçilen kubbe, dıştan onikigen kasnağa oturan onikigen piramidal külahla örtülü ve iki katlıdır (Fotoğraf 4). Türbeye doğu eyvanın kuzey duvarındaki yedi basamaklı merdivenle ulaşılan dışbükey iki silme ve yüzeyi bezemeli bir bordürle çevrilen dikdörtgen kapıdan girilmektedir.Yapının kuzey duvarının ekseni ile doğu duvarında eksenin güneyinde birer pencere yer alır. Bugün türbede özgün olmayan bir sanduka vardır ${ }^{23}$. Caca Bey’in sandukasının bulunduğu alt kata dört basamaklı bir merdivenle inilmektedir. Türbenin üst kat/ziyaret odasının duvarlarını üst seviyede sınırlayan yatay şeritte firuze çinilerin kuşattığı patlıcan moru çinilerle uygulanmış sülüsle yazılmış Bakara (255), Mümin (39), Nur (36-38) surelerinin ayetlerinden seçilmiş kitabeler dikkati çeker ${ }^{24}$. Yapının içinde kaba yonu ve düzgün kesme taş kullanılmıştır.

Medrese ve Türbenin banisi Kırşehir Emiri Nureddin Caca Bey’in ölüm tarihi kesin olarak bilinmemektedir. Caca Bey'in Anadolu'da Selçuklular ve İhanlılar arasındaki siyasi mücadelelerin yaşandığı bir ortamda, yaklaşık 13 . Yüzyılın sonuna doğru öldüğü ve inşa ettirdiği medresesinin içindeki türbesine gömüldüğ̈̈ anlaşılmaktadır²5.

\section{Ana Eyvana Bitişik Türbeler}

Anadolu Selçuklu medreselerinde çoğunlukla giriş eyvanının karşısında konumlanan ve dikey eksende bulunan ana eyvan, diğer eyvanlardan geniş ve yüksek tutularak yapıya hâkim konumuyla öne çıkmaktadır. Dolayısıyla ana eyvanın bitişiğindeki mekânların türbe yapılması da akılcı bir yaklaşımdır. Mengücekli

\footnotetext{
23 Kuran, Medreseler, s. 56; Sözen, Anadolu Medreseler II, s. 17; Tuncer, Kümbetler I, ss. 175-178, Önkal, a.g.e., ss. 404-408.

${ }^{24}$ Tuncer, Kümbetler I, s. 176; Yetkin, a.g.e., s. 94; Önkal, a.g.e., s. 406; Arıkan-Tuğutlu -Eraslan, a.g.e., s. 26.

25 Arıkan-Tuğutlu-Eraslan, a.g.e., ss. 3-6; Şimşek, a.g.e., ss. 10-20.
} 
eseri Divriği Turan Melek Darüşşifası (1228-1229) ile Konya Karatay (12511252) ve Tokat Gök (1275) medreselerinde ana eyvanın bitişiğindeki mekânlar türbe olarak tasarlanmıştır (Plan 3a-c). Divriği Turan Melek Darüşşifası taç kapısı üzerindeki kitabelerine göre 1228-1229 yılında Mengücekli hükümdarı Ahmed Şah’ın eşi Turan Melek tarafindan Ahlatlı Mimar Hürremşah'a yaptırılmıştır. Konya Karatay Medresesi taç kapısı üzerindeki kitabesi ve vakfiyesine göre 12511252 yılında Selçuklu devlet adamı Celaleddin Karatay tarafindan inşa edilmiştir. Tokat Gök Medrese'nin kitabesi ve vakfiyesi olmadığı için yapım tarihi ve banisi kesin olarak bilinmemektedir. Bazı araştırmacılar Tokat Gök Medrese'nin mimari ve süsleme özellikleri ile Selçuklu Veziri Muiniddin Süleyman Pervane’nin bu çevredeki etkinliklerini dikkate alarak, yapının yaklaşık 1275 yılında Pervane tarafindan yaptırılmış olabileceğini ileri sürmektedir ${ }^{26}$.

Divriği Turan Melek Darüşşifası Ulu Camii yapı topluluğu içinde yer alır. Kuzey-güney yönünde dikdörtgen planlı yapı topluluğunda kuzeyde cami ile güneyine bitişik darüşsifa ve darüşşifanın içinde türbe bulunur. Darüşsifa kapalı avlulu, üç eyvanlı, batı kanadı çift katlı bir yapıdır (Plan 3a). Yapıda avlunun doğu kanadında, dikey eksendeki ana eyvanın kuzeyine bitişik doğu-batı yönünde dikdörtgen planlı mekân tek katlı türbe olarak yapılmıştır ${ }^{27}$. Bu mekân bir kemerle doğuda kare planlı, içten üzeri tromplarla geçilen kubbe, dıştan sekizgen piramidal külahla örtülü, batıda dikdörtgen planlı ve sivri tonoz örtülü iki birime ayrılmıştır. Yapıda sekizgen kasnak ve piramidal külahıyla dışa yansıyan türbenin dıştan algısı güçlüdür (Fotoğraf 5). Türbe batı duvarının güney köşesindeki kapı ile avluya, kuzey duvarında eksenin batısındaki bir pencere ile camiye, doğu duvarında eksene simetrik üst seviyede bulunan birer mazgal pencere ile dışa açılmaktadır. Yapının içinde darüşşifanın banisi Turan Melek, caminin banisi Ahmet Şah ile diğgerleri yakınlarına ait üç sıra halinde dizilmiş on altı sanduka bulunmaktadır. Turan Melek ve eşi Ahmet Şah’ın firuze renkli altıgen çinilerle kaplanmış sandukaları

26 Bu gruptaki medreseler ve darüşşifa için bkz. Osman Turan, "Selçuklu Devri Vakfiyeleri III. Celâleddin Karatay, Vakıfları ve Vakfiyeleri", Belleten, XII/12, (1948), ss. 17-171; Kuran, Medreseler, ss. 51-53, 61-62, 96-99; Mahmut Akok, "Konya'da Karatay Medresesi Rölöve ve Mimarisi”, Türk Arkeoloji Dergisi, 18/2, (1970), ss. 5-28; Sözen, Anadolu Medreseler I, ss. 213-221; Sözen, Anadolu Medreseleri II, ss. 8-14, 63-68; İbrahim Numan, "Tokat Gök Medrese İle Yanındaki Yapı Bakiyesi Arasındaki Mimari Münasebet", Suut Kemal Yetkin'e Armağan, Hacettepe Üniversitesi Yayınları Ankara 1984, ss. 249-261; Iş̧k Aksulu, "Bir Selçuklu Mirası Beşiği-Tokat Kenti", I. Uluslararası Selçuklu Kültuir ve Medeniyeti Kongresi, 11-13 Ekim 2000, Bildiriler I, Selçuklu Araştırmaları Merkezi Yayınları, Konya 2001, ss. 1-17, 487-502; Doğan Kuban, Divriğ̈i Mucizesi,3. bs, Yapı Kredi Yayınları, İstanbul 2003, s. 54; Yaşar Erdemir, Karatay Medresesi Çini Eserler Müzesi, Konya Valiliği İl Kültür ve Turizm Müdürlüğü Yayınları, 3. bs., Konya 2015.

27 Tuncer, Kümbetler I, ss. 236-238; Cantay, a.g.e., ss. 51-55; Önkal, a.g.e., s. 394-398; Kuban, a.g.e., s. 54. 
diğerlerinden daha büyüktür. Sandukaların baş ve yan yüzlerinde altıgen firuze ve patlıcan moru çiniler üzerine altın yaldızla "yâ Allah" yazılmıştır ${ }^{28}$. Darüşşifa ve türbede düzgün kesme taş kullanılmıştır. Araştırmacılardan Doğan Kuban, cami ve darüşşifadaki süsleme yoğunluğuna dikkat çekerek, türbenin bezemesiz kalmasını yapının tamamlanmamış olabileceğine bağlamaktadır ${ }^{29}$.

Konya Karatay Medresesi'nde ana eyvanın bitişiğindeki kare, Tokat Gök Medrese'de ana eyvanın bitişiğindeki dikdörtgen planlı mekânlar türbe olarak yapılmıştır. Karatay örneğinde avluya hâkim konumdaki tek eyvanın bitişiğindeki birim, türbe için en uygun mekân olmuştur ${ }^{30}$.

Konya Karatay Medresesi kapalı avlulu, tek eyvanlı ve tek katlı bir yapıdır (Plan 3b). Medresede avlunun batı kanadı eksenindeki ana eyvanın güneyine bitişik mekân türbe olarak değerlendirilmiştir (Fotoğraf 6). Türbe kare planlı, üzeri üçgen kuşakla geçilen kubbe ile örtülü, bugün tek, özgününde iki katlı bir yapıdır ${ }^{31}$. Mekânın doğu duvarı kuzey köşesindeki kapı avluya, batı duvarı ekseninde dışa, kuzey duvarı yaklaşık ekseninde eyvana açılan birer pencere bulunur. Yapının içinde özgününde çini kaplı olduğu belirtilen bir sanduka vardır. Medrese ve türbenin banisi Celaleddin Karatay’ın yapının inşasından yaklaşık üç yıl sonra (1254) Kayseri'de öldüğü, Konya'daki medresesinin içindeki türbesine (alt katına) gömüldüğü belirtilmektedir ${ }^{32}$. Türbenin duvarları sıvalı olduğundan malzemesi algılanamamaktadır. Kubbeye geçiş ve kubbede tuğla kullanılmıştır. Kubbe yüzeyi çift yönlü eğik istifli/başak örgülü tuğlalarla biçimlenen balıksırtı motifleriyle bezenmiştir ${ }^{33}$. Medresede avluyu ve türbeyi örten kubbeler dışa yansıyan önemli elemanlardır.

28 Saadet Taşkın,. "Anadolu Selçuklularında Çinili Lahitler", Sanat Tarihi Yillĭğ, IV, (1970-1971), ss. 238-239; Orhan Cezmi Tuncer, "Sivas-Divriği Melîke Turan Şifahanesi’ndeki Türbe", Divriği Ulu Camï ve Darüsssifası, Derleyen. Yılmaz Önge-İbrahim Ateş-Sadi Bayram, Vakıflar Genel Müdürlüğ̈̈ Yayınları, Ankara 1978., ss. 156-157; Yılmaz Önge, "Bugünkü Bilgilerimizin Işı̆̆ı Altında Divriği Ulu Camii ve Darüşşifası", Divrĭgi Ulu Camï ve Darüsş̧ifası, Derleyen, Yılmaz Önge-İbrahim Ateş-Sadi Bayram, Vakıflar Genel Müdürlüğü Yayınları, Ankara 1978, s. 50; Tuncer, Kümbetler I, s. 236; Önkal, a.ge.e, s. 395; Kuban, Divriğgi Mucizesi, s. 54; Arık, "Anadolu Selçuklu Toplum Hayatında Çini”, s. 37.

29 Kuban, a.g.e., s. 54.

30 Kuran, Medreseler, s. 101; Demiralp, Erken Osmanl Medreseleri, s. 216.

31 Kuran, Medreseler, s. 52; Akok, "Konya Karatay...", s. 7, 12; Sözen, Anadolu Medreseleri II, s. 65; Erdemir, Karatay Medresesi, ss. 103-105.

32 Turan, "Vakfiyeler III Celaleddin Karatay...", s. 42; İbn Bibi, El Evamirü'l-Ala'iye Fi'l-Umuri'l-Ala'iye (Selçuk Name) II, Haz., Mürsel Öztürk, Kültür Bakanlığı Yayınları, Ankara 1996, s. 136; Zehra Odabaş1, "Celaleddin Karatay'ın Hayatı ve Siyasi Kariyeri”, Tarihçiliğe Adanmıs Bir Ömür: Prof. Dr. Nejat Göyünç'e Armağan, Ed, Hasan Bahar, Mustafa Toker, M. Ali Hacıgökmen, H. Gül Küçükbezci, Selçuk Üniversitesi Türkiyat Araştırmaları Enstitüsü Yayınları, Konya 2013, s. 588; Erdemir, Karatay Medresesi, s. 104.

33 Bakırer, Selçuklu Tuğla Kullanımı, I, s. 407; Erdemir, Karatay Medresesi, s. 102. 
Tokat Gök Medrese açık avlulu, iki eyvanlı ve çift katlı bir yapıdır (Plan 3c). Medresede avlunun dikey ekseninde güney kanattaki ana eyvanın batısına bitişik doğu-batı yönünde dikdörtgen planlı mekân türbe olarak düzenlenmiştir ${ }^{34}$. Bu mekânın örtüsü iki kemerle ortada kare planlı ve üzeri üçgen kuşakla geçilen kubbe, iki yanda dikdörtgen planlı ve sivri tonoz örtülen üç birime ayrılmıştır. Türbenin kuzey duvarının doğu köşesinde avluya açılan bir kapı vardır. Yapının içinde farklı boyutlarda yirmi sanduka yer alır ${ }^{35}$.

Tokat Gök Medrese'nin kitabesi olmadığı için yapım tarihi ve banisi kesin olarak bilinmemektedir. Araştırmacılar yapının mimari ve süsleme özelliklerine dayanarak yaklaşık 1275 yılında Selçuklu Veziri Muiniddin Pervane tarafindan yaptırılmış olabileceğini ileri sürmektedir ${ }^{36}$.

\section{Eyvanlardan Birinin Türbe Olarak Tasarlandı̆̆ı Örnek}

Anadolu Selçuklu medreseleri ve darüşşifalarında eyvanlardan birinin türbe olarak tasarlandığı yapılar çok azdır. Bu grubun örneğini Sivas I. İzzeddin Keykavus Darüşşifası ve Türbesi oluşturmaktadır. Keykavus Darüşşifası taç kapısı üzerindeki kitabesi ve vakfiyesine göre 1217 yılında, darüşşifanın içindeki I. İzzeddin Keykavus Türbesi ise kuzey cephesindeki kitabesine göre 1220 tarihinde Selçuklu Sultanı I. İzzeddin Keykavus tarafından yaptırılmıştır ${ }^{37}$. Ayrıca türbenin kuzey cephesinde, batıdaki pencerenin üzerinde iki kartuş içinde "Ameli Ahmed, bin

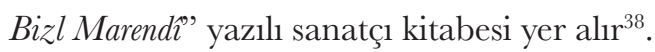

34 Kuran, Medreseler, ss. 96-99; Sözen, Anadolu Medreseleri II, ss. 213-220; Cantay, a.g.e., ss. 60-66; Aksulu, a.g.m., s. 8.

${ }_{35}$ Kuran, Medreseler, ss. 97; Sözen, Anadolu Medreseleri I, s. 219; Fazilet Koçyiğit, "Üslupsal Özellikleri Temelinde Tokat Gök Medrese'ye Yeniden Bakış", Zeitschrift fuir die Welt der Türken/fournal of World of Turks, $7 / 2$ (2015), s. 245.

36 Kuran, Medreseler, ss. 99; Sözen, Anadolu Medreseleri I, ss. 214.

37 Sivas I. İzzeddin Keykavus Darüşşifası ve Türbesi için başlıca yayınlara bkz. Melih Cevdet, "Sivas Darüşşifası Vakfiyesi ve Tercümesi”, Vakıflar Dergisi, I (1938), ss. 35-38; Sedat Çetintaş, Sivas Darüsşifası 6141217, İbrahim Horoz Basimevi, .Istanbul 1953, ss. 13-122; Kuran, Medreseler, ss. 103-104; Sözen, Anadolu Medreseleri I, ss. 90-101; Orhan Cezmi Tuncer, "Son Kazıların Işı̆̆1 Altında Sivas Şifahanesi Plan $\imath$ ", I. Milletlerarası Türkoloji Kongresi, İstanbul, 15-20. X. 1973, Tebliğler, 3. Türk Sanatı Tarihi, Tercüman Gazetesi ve Türkiyat Enstitüsü Yayınları, İstanbul 1979, ss. 911-951; Tuncer, Kümbetler I, ss. 232-238; Burhan Bilget, I. İzeddin Keykavus Darüsssifası, Kültür Bakanlığı Yayınları, Ankara 1990; Cantay, a.g.e., ss. 45-50; Önkal, a.g.e., ss. 383-391; Ali Haydar Bayat, "Sivas Darüşşifası'nın Bilinen ve Bilinmeyen Kitabeleri”, Selçuklular Döneminde Sivas Sempozyumu Bildirileri, 29 Eylül-1 Ekim 2005, Sivas 2006, ss. 351-364; Nermin Şaman Doğan, "Selçuklu Döneminden İki Sultanî Külliye (Kayseri Gevher Nesibe ve Sivas I. İzzeddin Keykavus Darüşşifaları)", Uluslararası Katılımh XV. Ortaçağ ve Türk Dönemi Kazılan ve Sanat Tarihi Araştırmalan Sempozyumu, Anadolu Üniversitesi-Eskişehir, 2011, I, Anadolu Üniversitesi Yayınları, Eskişehir 2 012, ss. 299-308.

38 Sanatçı kitabesi için bkz. Bayburtluoğlu, a.g.e., ss. 217-219; Sönmez, a.g.e. s. 214, 216-217. 
Sivas I. İzzeddin Keykavus Darüşşifası açık avlulu, dört eyvanlı ve tek katlı bir yapıdır (Plan 4). Darüşşifada avlunun yatay eksenindeki güney eyvanın kuzeyi duvarı kapatılarak türbeye dönüştürülmüştür (Fotoğraf 7-8). Türbe kare planlı, üzeri içten üçgen kuşaklarla geçilen kubbe, dıştan ongen kasnağa oturan piramidal külahla örtülü ve iki katlıdır². Yapının alt katı/mezar odası bugün algılanamamaktadır. Türbenin ziyaret odası/mescit mekânının güney duvarı ortasında dikdörtgen nişli, beş sıra mukarnas kavsaralı dıştan iki bordürle kuşatılan mihrap bulunur ${ }^{40}$. Yapının güney duvarında eksene simetrik alt seviyede büyük, üst seviye küçük boyutlu birer dikdörtgen pencere, kuzey duvarında eksende bir kapı ile simetriğinde aynı kurguda büyük boyutlu birer pencere yer alır. Türbenin ön/ kuzey cephesinde, üst seviyede kapı ve pencerelerin üzerinde uzanan yatay şeritte sülüsle yazılmış tek satırlık inşa kitabesinde "Bu daracık mezarlara girmek üzere geniş saraylardan çıkarldık. Ne yazık ki (bu ölüm hadisesinde) zenginliğimin bana faydası olmad,, saltanatım mahvoldu, ... ahrete intikal ve göçüs olayı 617 senesinin Şevval ayını dördüncü günü gerçekleşti” yazıları ölüm karşısındaki çaresizliği ve ölümün kaçınılmazlığını vurgulamaktadır $^{41}$. Kitabe verileri darüşşifasının inşassından (1217) yaklaşık üç yıl sonra bu türbenin (1220) yaptırıldığını göstermektedir. Türbenin ön/kuzey cephesinde revaklara ve avluya açılan dikdörtgen çerçeveli, sivri kemerli alınlıklı dikdörtgen bir kapı ile simetriğindeki pencereler ve dıştan ongen kasnağın her bir yüzü sırl--sırsız tuğla ve çini mozaik tekniğinde çinilerle süslenmiştir ${ }^{42}$. Yapının içinde farklı boyutlarda on beş sanduka bulunmaktadır. Keykavus’un büyük boyutlu ve yüksek sandukası çini ile kaplanmıştır ${ }^{43}$. Darüşşifanın özellikle türbe bölümünde sanatçı kitabesinden de anlaşıldığı gibi komşu kültür çevresinden gelen İanlı-Marendli sanatçının çalıştığı çini programının zenginliğinden anlaşılmaktadır. Ayrıca yapının güney cephesinde türbenin bulunduğu bölüm ile ongen kasnağının yüksek tutularak, yoğun süslenmesi türbenin algısını artırmıştır.

39 Kuran, Medreseler, ss. 103-104; Sözen, Anadolu Medreseleri I, ss. 90-101; Tuncer, Kümbetler I, ss. 232236; Önkal, a.g.e., ss. 383-390; Ömür Bakırer, "Sivas Keykavus Darüşşifası’nda Taş, Tuğla ve Çini”, Ortaçă̆’da Anadolu Prof. Dr. Aynur Durukan'a Armağan, Ed., Nermin Şaman Doğan, Renkmay Basımevi, Ankara 2002, ss. 75-90.

40 Ömür Bakırer, Onüç ve Ondördüncü Yüzynllarda Anadolu Mihraplan, Türk Tarih Kurumu Yayınları, Ankara 1976. ss. 139-140.

41 Çetintaş, a.g.e., ss. 15-16; Önkal, a.g.e., ss. 387-388; Bayat, “Sivas Darüsssifa Kitabeler...”, ss. 356-357.

42 Bakırer, Selçuklu Tuğla Kullanımı I, s. 283-302; Selçuklu Tuğla Kullanımı II, Res. 127, 154-156; Yetkin, a.g.e., ss. 36-40; Bakırer," Sivas Keykavus Darüsşifa...", ss. 75-90; M. Oluş Arık, "Anadolu Selçuklu ve Beylikler Dönemi Dini ve Kamusal Kapılannda Çini”, Anadolu Toprağınn Hazinesi; Çini Selçuklu ve Beylikler Çağ Çinileri, Ed. Rüçhan Arık-Oluş Arık, Kale Grubu Kültür Yayınları, İstanbul 2007, ss. 47-53; Arık, "Anadolu Selçuklu Toplum Hayatinda Çini", s. 34.

${ }_{43}$ Taşkın, a.g.m., ss. 240-242; Yetkin, a.g.e., ss. 39-40; Oluş Arık, "Anadolu Selçuklu ve Beylikler Dönemi Dini ve Kamusal Yapularnda Cini”, ss. 52-53. 
Selçuklu Sultanı I. İzzeddin Keykavus'un Sivas'taki Darüşşifası'nı inşa ettirdiği 1217 yllından sonra başkent Konya’ya yöneldiği ve Selçuklu dönemi İç Kalesi'nin içinde bulunan Konya Alaeddin Camii’nin yapımına devam ettiği anlaşılmaktadır. Alaeddin Camii’nin avlusunun kuzey cephesinin batı bölümünde üç dilimli kemerli niş içinde sülüsle yazılmış dört satırlık kitabe “... Bu mübarek mescit ve türbenin yapılmasın, Galib Sultân, fetihler babası, ...şehit Sultan Keyhüsrev oğlu Keykavus, bitevellî, kul, Atabekî Ayaz’a 616 H./1219 M. senesinde emretti" bilgilerini içerir $^{44}$. Bu kitabe bilgisi cami ve avlunun batısındaki tamamlanmamış türbenin Sultan I. İzzeddin Keykavus'un kendisi için inşa ettirdiğini ortaya koymaktadır ${ }^{45}$.

Keykavus'un siyasi yaşamında Konya Alaeddin Camii ve Türbesi’nin yapımına devam ettiği 1219 yılı, sultanın başarısız Halep Seferi sonrasında yaşanan siyasi gerginliklerin etkisiyle verem hastalığının ilerlediği bir dönem olmalıdır. Sultanın Konya'da inşa ettirdiği Türbesi’nin yarım kalmasının nedeni, Keykavus’un yaşadığı kararsızlıklar ve sıkıntılarla Sivas'a geri dönmesi, burada yaptırdığı Darüşşifası'nın içindeki türbesine gömülmesi ile ilişkilidir ${ }^{46}$. Ayrıca Selçuklu Sultanı Keykavus'un hastalığı sürecinde kararını değiştirmesi, baniliğini üstlendiği darüşşifanın/hastanenin içinde yaptırdığı türbeye kendi isteği ile gömülmesi de oldukça anlamlıdır.

\section{B. Medrese Kütlesi Dişında Olan Türbeler}

\section{Ana Eyvanın Arka Cephesine, Dikey Eksenine Bitişik Türbeler}

Anadolu Selçuklu medreselerinden bazılarında bani türbeleri yapıların farklı cephelerine dıştan bitişik inşa edilmiştir (Plan 5a-c). Atabey Ertokuş, Erzurum Çifte/Hatuniye ve Erzurum Yakutiye medreselerinde avluların dikey eksenlerinde, yapılara hâkim konumdaki ana eyvanların arka cephesine bitişik, bu eyvanlarla kapı ya da pencereler aracılığı ile bağlantılı türbeler karşımıza çıkmaktadır. Medreselerde arka cepheyi hareketlendiren, taçlandıran bu türbeler dönemin bağımsız örnekleri gibi dıştan (kaide, gövde ve külahları) tümüyle okunabilmektedir.

44 Remzi Duran, Selçuklu Devri Konya Yapı Kitâbeleri (İnşa ve Ta'mir), Türk Tarih Kurumu Yayınları, Ankara 2001, ss. 37-38, Resim 8; Remzi Duran, "Konya Alaeddin Camisi Kitabeleri”, Anadolu Selçuklulan ve Beylikler Dönemi Uygarlığ 2, Ed. Ali Uzay Peker- Kenan Bilici, Kültür ve Turizm Bakanlığı Yayınları, Ankara 2006, ss. 23-29.

45 Yaşar Erdemir, "Konya Alâeddin Camii'nin Avlusundaki Bitmemiş Yapının Mahiyeti Hakkında", Selçuklu'dan Osmanli’ya Bilim, Kültür ve Sanat Prof. Dr. Mikâil Bayram’a Armağan, Konya 2009,ss. 231-250.

46 İbn Bibi, a.g.e., s. 207-218; Erdemir, “Konya Alaeddin Bitmemiş Yapı...”, ss. 237-238; Şaman Doğan, "İki Sultanî Külliye...",, s. 299-308. 
Atabey Ertokuş Medresesi taç kapısı üzerindeki kitabesi ve vakfiyesine göre Selçuklu devlet adamı Mübarizeddin Ertokuş tarafindan 1224 yılında, Erzurum Çifte Minareli/Hatuniye Medresesi 1285-1290 yıllarında, Erzurum Yakutiye Medresesi taç kapısı üzerindeki kitabesine göre Cemaleddin Hoca Yakut tarafindan 1310-1311 yılında yaptırılmışıır ${ }^{47}$.

Medreselerde avlunun dikey ekseninde konumlanan, diğer eyvanlardan geniş, yüksek ve derin olan, avlu zemininden yüksek kurgusuyla öne çıkan ana eyvanın arka cephesine diştan bitişik türbeler yer almaktadır. Bu grubun ilk örneğini Atabey Ertokuş Medresesi ve Türbesi oluşturmaktadır. Ertokuş Medresesi kapalı avlulu, tek eyvanlı ve tek katlıdır (Plan 5a). Örnekte taç kapı, kapalı avlu, havuz, eyvan/mescit ve eyvanla bağlantılı dıştan bitişik türbenin dikey eksende yer alması bu birimleri öne çıkarmaktadır. Ertokuş Medresesi'nin batı cephesinin orta bölümüne diştan bitişik türbe yapılmıştır (Fotoğraf 9). Ertokuş Türbesi’nde doğu cephenin tümü ile güneydoğu cephenin yarısının medresenin batı cephesinin orta bölümüne ve içte eyvanın batı duvarına bitişik olması, türbeye eyvandan üç kapıyla girilmesi farklı bir uygulamadır. Türbe kare kaideli, içten ve diştan sekizgen gövdeli, içten kubbe, dıştan sekizgen piramidal külahla örtülü ve çift katlıdır ${ }^{48}$. Bugün türbeye eyvanın/mescidin batı duvarında bulunan üzerlerinde sivri kemerli pencereleri olan üç dikdörtgen kapıdan girilmektedir. Bazı araştırmacılar özgününde eyvandan türbeye tek, bazıları ise üç kapıyla girildiğini öne sürmektedir ${ }^{49}$. Türbe-eyvan bağlantısında eyvan ve türbenin aynı düzlemde olmaması, bir başka deyişle eyvandaki kapıların açıldığı merdivenlerle çıkılan koridorlar aracı̆ğ ile ulaşılan türbenin daha yüksekte bulunması, türbenin alt katı/ mezar odası kapısının kapanmasına ve algılanmamasına neden olmuştur. Ertokuş Medresesi ve Türbesi'nin yapım sürecine ilişkin ileride yapılacak yeni çalışmalar

47 Medreseler için bkz. Osman Turan, "Selçuklu Devri Vakfiyeleri II Mübarizeddin Er-Tokuş ve Vakfiyesi", Belleten, XI /43, (1947), ss. 415-430; Suut Kemal Yetkin, "Çifte Minareli Medrese", Illahiyat Fakültesi Dergisi, II-III (1952), ss. 46-49; Oktay Aslanapa, "Selçuk Devlet Adamı Mübarizeddin Ertokuş Tarafindan Yaptırlan Abideler", Íslam Tetkikleri Enstituisü Dergisi, II/1 (1957), ss. 97-111;J. M. Rogers,. "The Çifte Minare at Erzurum and the Gök Medrese at Sivas", Anatolian Studies, 15, (1965), ss. 64-85; Yllmaz Önge, "Emir Mübarezeddin Ertokuş'un Kümbeti ve Çinili Sandukası", Önasya, 3 (1967), ss. 14-15; Kuran, Medreseler, ss. 46-49, 116-127; Sözen, Anadolu Medreseleri I, ss. 64-74; Sözen, Anadolu Medreseleri II, ss. 1-7, 42-47; Tuncer, Kümbetler I, ss. 130-132; Orhan Cezmi Tuncer, Anadolu Kümbetleri 2 Beylikler ve Osmanh Dönemi, Sevinç Matbaas1. Ankara 1991, ss. 173-178, 183-187; Rahmi Hüseyin Ünal, Çifte Minareli Medrese (Erzurum), Kültür Bakanlığı Yayınları, Ankara 1989; Rahmi Hüseyin Ünal, Erzurum Yakutiye Medresesi, Kültür Bakanlığı Yayınları, Ankara 1992; Önkal, a.g.e., ss. 74-79, 196-200; Nermin Şaman Doğan, Atabey Ertokuş Medresesi ve Türbesi, Bizim Büro Basımevi, Ankara 2013.

48 Önge, "Ertokus Kümbeti...”, ss. 14-15; Tuncer, Kümbetler I, ss. 130-132; Önkal, a.g.e., ss. 74-79.

49 Önge, "Ertokus Kümbeti...", ss. 14-15; Tuncer, Kümbetler I, ss. 131; Önkal, a.g.e., ss. 74-79; Şaman Doğan, Atabey Ertokus, ss. 59-60. 
(kazı ?) sonucunda bu konunun aydınlatılabileceğini düşünmekteyiz. Medresede avluya hâkim olan tek eyvanının mescit olması, dikdörtgen nişli, beş sıra mukarnas kavsaralı mihrabının bulunması, eyvana açılan türbe kurgusu mescit-türbe ilişkisini artırmıştır ${ }^{50}$. Türbede dikdörtgen prizmal, delik işi/ajur tekniğinde firuze renkli çinilerle bezenmiş bir sanduka yer alır ${ }^{51}$. Yapıda moloz taş, kaba yonu taş, düzgün kesme taş, tuğla, çini ve devşirme malzeme kullanılmıştır. Türbenin kaide ve cephelerinde düzgün kesme taş, türbeyi medreseyi bağlayan duvarlarda kaba yonu taş, içte moloz taş, cephelerin köşelerindeki plasterler, pencere kemerleri ve külahta tuğla kullanımı görülür. Cephelerde bir sıra kahverengi, bir sıra beyaz kesme taşların dizilimi ile renk almaşıklığı uygulanmıştır. Devşirme malzeme türbeye giriş kapılarının lento ve söveleri, içten ortadaki kapının kemeri ile eyvandan türbeye ulaşılan merdiven basamaklarında kullanılmıştır ${ }^{52}$.

Atabey Ertokuş Medresesi'nin banisi Selçuklu devlet adamı Mübarizeddin Ertokuş'tur. Mübarizeddin Ertokuş, uzun süre Isparta ve Antalya bölgesinin subaşılığını/valiliğini, son olarak da Erzincan'da Melik Gryaseddin Keyhüsrev’in atabeyliğini yapmıştır ${ }^{53}$. Başarılı bir devlet adamı olan Mübarizeddin Ertokuş’un ölümüne ilişkin bilgilerin olmaması üzücüdür. Medresenin bulunduğu Atabey ve çevresi Ertokuş'un yaşadığı ve bildiği, kervansaray, cami, medrese, türbe gibi yapılarını inşa ettirdiği bir bölge olmuştur. Bu yapılar arasında Atabey Ertokuş Medresesi ile bitişiğine kendi türbesini inşa ettirmesi Ertokuş’un tercihini, bölgeye özel ilgisini göstermektedir.

Atabey Ertokuş Medresesi ve Türbesi'ndeki uygulama daha sonra Anadolu'da Erzurum Çifte Minareli/Hatuniye (1285-1290) ve Erzurum Yakutiye (1310-1311) medreselerinde de karşımıza çıkmaktadır ${ }^{54}$. Sunulan üç örnekte de taç kapıgiriş eyvanı/mekânı-avlu-ana eyvan-türbenin dikey eksende dizilimi, bu yöndeki vurguyu güçlendirmektedir.

50 Bakırer, Anadolu Mihraplan, ss. 148-49, Şek. 23, Res. 62-63.

51 Taşkın, a.g.m., s. 243; Tuncer, Kümbetler I, ss. 132; Önkal, a.g.e., s. 77.

52 Tuncer, Kümbetler I, ss. 130-132; Önkal, a.g.e.,ss. 75-77; Nermin Şaman Doğan, "Isparta ve Çevresindeki Selçuklu-Beylikler Dönemi Yapılarında Devşirme Malzeme Kullanımı”, Vakıflar Dergisi, 26, (1997). ss. 347-354; Şaman Doğan, Atabey Ertokuş, s. 66.

53 Aslanapa, a.g.m., ss. 97, 104-111; Hasan Geyikoğlu, “Antalya’nın İlk Türk Mülki Amiri ve Kumandanı Mübarizettin Ertokuş'un Faaliyetleri ve Eserleri”, Adalya, V (2002), ss. 187-198; Nermin Şaman Doğan, "Selçuklu Döneminde Siyasi ve Bani Kimliği ile Mübarizeddin Ertokuş", Hacettepe Üniversitesi Edebiyat Fakültesi Dergisi, 27/1, (2010), ss. 231-251.

54 İbrahim Hakkı Konyalı, Abideleri ve Kitabeleri İle Erzurum Tarihi, Ercan Matbaası, İstanbul 1960, ss. 302-307, 336-360; Kuran, Medreseler, ss.116-124, 124-127, şek. 64-67; Sözen, Anadolu Medreseleri II, ss. 1-7, şek. 1; Tuncer, Kümbetler I, ss. 26-28, 33-34; Ünal, Erzurum Çifte Minareli, ss. 1-14, şek. 1-2; Ünal, Erzurum Yakutive, ss. 1-11, şek. 1 
Erzurum Çifte Minareli/Hatuniye Medresesi açık avlulu, dört eyvanlı ve iki katlı bir yapıdır (Plan 5b). Medresede avlunun dikey ekseninde diğer eyvanlardan daha derin olan ana/güney eyvanın güney cephesine bitişik iki katlı türbe yer alır (Fotoğraf 10). Türbenin alt katı/mezar odası dıştan kare, içten haç planlı ve haç tonoz örtülü, üst katı/ziyaret mekânı/mescidi dıştan ve içten onikigen planlı, içten kubbe, dıştan konik külahla örtülüdür ${ }^{55}$. Yapının mezar odası ve üst kat/mescide medresenin ana eyvanındaki merdivenlerle ulaşılan kapılardan girilmektedir. Türbenin kuzey, kuzeybatı ve kuzeydoğu cepheleri (üç cephesi) medresenin güney cephesinin orta bölümüne, içten ana eyvana bitişiktir. Türbenin cephelerinde dışbükey/kaval ve kademeli düz silmelerle biçimlenen sivri kemerli yüzeysel nişler ile doğu, batı, kuzeydoğu ve kuzeybatı cephelerde alt seviyede beş sıra mukarnas kavsaralı dikdörtgen, üst seviyede sivri kemerli pencereler bulunur. Yapıda onikigen gövdenin üst bölümü silindiriğge dönüşerek konik külahla örtülmüştür. Türbenin mescit bölümündeki pencereler yedi sıra mukarnas kavsaralı, pencere aralarındaki dönüşümlü dizilen ve örtü seviyesine kadar yükselen yarım daire nişler altı sıra mukarnas kavsaralıdır. Ayrıca bu pencerelerin üzerinde sivri kemerli nişler yer alır. Bugün sanduka bulunmayan türbede düzgün kesme taş kullanılmıştır. Yapının cephelerinde gövdenin üst bölümünde/saçak altında kademeli silmelerle sınırlanan geometrik bezemeli bir bordür ile külahın yüzeyini hareketlendiren silmelerle biçimlenen sivri kemerli süslemeler dikkati çeker.

Çifte Minareli/Hatuniye Medresesi ve Türbesi'nin kitabesi ve vakfiyesi olmadığı için yapım tarihi ve banisi tartışmalıdır. Medreseyle ilgili en ayrıntılı çalışma Haluk Karamağaralı tarafindan yapılmıştır. Karamağaralı, medrese ve türbenin birlikte inşa edildiğini, Şehzade Keyhatu'nun eşi Padişah Hatun tarafindan 1285-1291 yıllarında yaptırıldı̆̆ını ileri sürmektedir ${ }^{56}$. Yapının inşa edildiği tarihsel süreç ile mimari özelliklerini tartışan bazı araştırmacılar da aynı görüşe katılmaktadır ${ }^{57}$. Daha sonra medreseyle ilgili ayrıntılı bir çalışma Osman Gürbüz tarafından yapılmıştır ${ }^{58}$. Araştırmacı Erzurum Çifte Minareli Medrese’nin

55 Suut Kemal Yetkin, "Çifte Minareli Medrese", İlahiyat Fakültesi Dergisi, II-III (1952), 46-49; Konyall, Erzurum, ss. 356-359; Ünal, Erzurum Çifte Minareli, ss. 12-14; Tuncer, Kümbetter 2, ss. 173-178; Abdülselam Uluçam, "Erzurum'daki Çifte Minareli Medrese Üzerine Yeni Bir Yorum", XI. Türk Tarih Kongresine Sunulan Bildiriler, II, (1994), ss. 749-758; Önkal, a.g.e.,ss. 196-200.

56 Haluk Karamağaralı, "Erzurum'daki Hatuniye Medresesi’nin Tarihi ve Banisi Hakkında Mülâhazalar", Selçuklu Araştrmalan Dergisi, 3, (1971), ss. 209-242.

57 Konyal, Erzurum, ss. 356-358. Kuran, Medreseler, ss.120-124; ; Sözen, Anadolu Medreseleri I, ss. 72-74; Ünal, Erzurum Çifte Minareli, ss. 54-56; Tuncer, Kümbetter 2, ss. 177-178; Önkal, a.ge.e, ss. 199-200.

${ }_{58}$ Osman Gürbüz, "Erzurum Çifte Minareli Medrese’nin Yapım Tarihi ve Bânîsi Hakkında Yeni Bir Yaklaşım", Atatïrk Üniversitesi Türkiyat Araştrrmalan Dergisi, 25 (2004). ss. 145-160. 
inşa tarihi ve banisini tartıştığı makalesinde yapının II. Gıyaseddin Keyhüsrev’in eşi Gürcü Hatun'dan doğan kızı Hundi Hatun adına üvey babası Muînedddin Süleyman Pervane tarafindan 1266-1277 yılları arasında yaptırılmış olabileceğini belirtmektedir ${ }^{59}$.

Erzurum Çifte/Hatuniye Medresesi ve Türbesi'ndeki kurgu daha sonra inşa edilen Erzurum Yakutiye Medresesi-Türbesi'nde de yinelenmiştir. Yakutiye Medresesi kapalı avlulu, üç eyvanlı, batı kanadı çift katlı bir yapıdır (Plan 5c). Örnekte kapalı avlunun dikey eksenindeki doğu/ana eyvanın doğu cephesine dıştan bitişik iki katlı türbe bulunur (Fotoğraf 11).Türbenin bugün girilemeyen alt katı/mezar odasının kare planlı ve çapraz tonozla örtülü olduğu belirtilmektedir ${ }^{60}$. Yapının üst katı/mescidi kare kaideli, dıştan onikigen, içten daire planlı ve silindirik gövdeli, içten kubbe, dıştan konik külahla örtülüdür ${ }^{61}$. Türbenin batı cephesinin tümü, kuzeybatı ve güneybatı cephelerinin yarısı medresenin batı cephesinin orta bölümüne, içten ana eyvana bitişiktir. Türbenin alt ve üst katına medresenin kuzeydoğu köşe odasılla bağlantılı olan kare planlı ve sivri tonoz örtülü mekânın güney duvarının doğu köşesindeki kapı ve merdivenlerle ulaşılmaktadır. Yapının dairesel planlı mescidinin güney duvarı ortasında yarım daire nişli mihrap ile doğu ve güneydoğu duvarları ekseninde dışa, batı duvarı ekseninde eyvana açlan birer pencere yer alır. Türbenin cepheleri çift sütuncelere atılan kademeli sivri kemerlerle biçimlenen yüzeysel nişlerle hareketlendirilerek, doğu ve güneydoğu cephelerinde alt seviyede dikdörtgen çerçeveli, altı sıra mukarnas kavsaralı dikdörtgen pencereler görülür. Onikigen gövdenin üst bölümü silindiriğe dönüşerek konik külahla örtülmüştür. Türbenin cephelerinde gövdenin üst bölümünde/saçak altında kademeli silmelerle sınırlanan geometrik bezemeli bir bordür ile külahın yüzeyinde yatay ve dikey silmelerle biçimlenen süslemeler dikkati çeker. Yapıda düzgün kesme taş kullanılmıştır.

Erzurum Yakutiye Medresesi ve Türbesi’nin eş zamanlı yapıldı̆̆g medresenin taç kapısı üzerinde bulunan "Bu medfenin yapılmasın 710 H./1310 M. yrlında Sultan Olcaytu'nun hükümdarlı günlerinde Sultan Gazan ve Bolugan Hatun'un yardımlar ile...

59 Gürbüz, a.g.m., s. 157.

60 Tuncer, Kümbetler 2, ss. 183-187; Ünal, Erzurum Yakutiye, ss. 6-7.

61 Konyal, Erzurum, ss. 302-306; İlhan Akçay, "Yakutiye Medresesi", Vakuflar Dergisi, 6 (1966), ss. 146 152; Sözen, Anadolu Medreseleri II, ss. 1-7; Nusret Çam, "Erzurum'daki Yakutiye Medresesi İle İlgili Bazı Mülahazalar", Vakuflar Dergisi, 20, (1988), ss. 292-295; Tuncer, Kümbetler 2, ss. 183-187; Ünal, Erzurum Yakutiye, ss. $1-3$. 
Cemaleddin Hoca Yakut emretti" yazılı inşa kitabesinden anlaşılmaktadır ${ }^{62}$. Medrese adının geçmediği bu kitabede türbe medfen/mezar yeri olarak tanımlanmıştır. Yapının banisi Cemaleddin Hoca Yakut'un kimliği hakkında bilgilerimiz sınırlıdır. Cemaleddin Hoca Yakut'un İlhanlı döneminde Erzurum ve Bayburt çevresinin valisi olabileceği düşünülmektedir ${ }^{63}$.

Anadolu'da Erzurum'daki Çifte Minareli/Hatuniye Medresesi açık avlulu, Yakutiye Medresesi kapalı avlulu medreselerin en büyük boyutlu anıtsal örneğidir. Bu yapılar medrese-türbe ilişkisinin yanı sıra İlhanlı döneminde değişen ve gelişim gösteren çifte minareli taç kapı-büyük boyutlu pencere-payandalar ve köşe kuleleri gibi ön cephe elemanlarıyla dikkat çekmektedir ${ }^{64}$.

\section{Medreselerin Gephelerinden Birine Bitişik Türbeler}

$\mathrm{Bu}$ bölümde medreselerin cephelerinden birine bitişik yapılan türbelerden örnekler sunulacaktır. Kayseri Mahperi Huand Hatun Medresesi'nde yan/ güney, Çay Ebû'l-Mücahid Yusuf Bin Yakub/Taş Medresesi'nde kuzey/ön cephelere bitişik türbeler yer alır (Plan 6a-b). Kayseri Mahperi Huand Hatun Medresesi bitişiğindeki caminin doğu ve batı taç kapıları üzerindeki kitabelerine göre Mahperi Huand Hatun tarafindan 1238 yılında, Çay Taş/Yusuf bin Yakub Medresesi taç kapısı üzerindeki kitabesine göre Yusuf bin Yakub tarafindan 1279 yılında inşa ettirilmiştir ${ }^{65}$.

Kayseri Mahperi Huand Hatun Külliyesi cami, türbe, medrese ve hamamdan oluşan büyük bir yapı topluluğudur ${ }^{66}$. Külliyede caminin kuzey cephesinin

${ }^{62}$ Konyal, Erzurum, s. 306; Çam, a.g.m., s. 292; Tuncer, Kümbetler 2, s. 186; ; Ünal, Erzurum Yakutiye, ss. $54-55$.

63 Çam, a.g.m., ss. 295-296; Tuncer, Kümbetler 2, s. 186; Ünal, Erzurum Takutive, s. 56.

64 Tuncer, Moğollar, ss. 26-28, 33-34.

65 Yapılar için bkz. Kuran, Medreseler, ss. 57-59, 70-73, 101-102; Sözen, Anadolu Medreseleri I, ss. 109113; Sözen, Anadolu Medreseleri II, ss. . 75-79; Tuncer, Kümbetler I, ss. 164-172; Önkal, a.g.e.,ss. 120-126, 275279; Mehmet Özkarcı, Afyon-Çay'da Ebû'l-Mücahid Tusuf Külliyesi, Kültür Bakanlığı Yayınları, Ankara 1996; Ara Altun, "Çay Medresesi", Türkiye Diyanet Vakfi Íslam Ansiklopedisi, 8 (1993), s. 239.

${ }_{66}$ Kayseri Mahperi Hatun Külliyesi için bkz. Aziz Ogan, "Kayseri'de Hovand veya Mahperi Hatun Külliyesiyle Mimari Bakımdan Kıymet Taşıan Kümbetler”, Türkiye Turing ve Otomobil Kurumu Belleteni, 167 (1955), ss. 3-4; Mahmut Akok, "Kayseri'de Hunad Mimari Külliyesinin Rölövesi”, Türk Arkeoloji Dergisi, XVI/1 (1967), ss. 5-44; Haluk Karamağaralı, "Kayseri'deki Hunad Câmiinin Restitüsyonu ve Hunad Manzumesinin Kronolojisi Hakkında Bazı Mülâhazalar”, Ankara Üniversitesi İlahiyat Fakültesi Dergisi, XXI (1976), ss.199-245; Mehmet Çayırdağ, "Kayseri Hunat Külliyesi”, Vakıf ve Kültür, $1 / 2$ (1998), ss. 23-26; Aynur Durukan, "Anadolu Selçuklu Sanatında Kadın Baniler", Vakıflar Dergisi, 27 (1998), ss. 16-18; Doğan Kuban, Selçuklu Căğında Anadolu Sanatı, Yapı Kredi Yayınları, İstanbul 2002, ss.134-137; S. Can, Terken Hatun'dan Valide Sultan'a Selçuklular Döneminde Kadon (1040-1308), Ufuk Ötesi Yayınları, İstanbul 2008, ss. 246, 249; Albert Gabriel, Kayseri Türk Anttlan, Haz. F. Yaman, Kayseri Enstitüsü Derneği Yayınları, Kayseri 2009, ss. 
batısına bitişik medrese ile medresenin güney cephesinin doğusuna bitişik, aynı zamanda caminin içinde bulunan Huand Hatun Türbesi medrese-türbe-cami bağlantıları ile farklı bir örnektir (Fotoğraf 12). Camide hariminin kuzeybatısında üç sahın genişliğinde ve iki sahın derinliğindeki alan Mahperi Huand Hatun Türbesi için ayrılmıştır ${ }^{67}$. Türbenin caminin içinde bulunması camiyle fiziksel bir bağlantı kurarken, medresede ana eyvanın güneyine bitişik üç bölüntülü mekânın güneydoğu köşe odasındaki kapıdan türbeye girilmesi medrese ile organik bir ilişki sağlamaktadır. Türbenin yer seçiminde yerinde önceden mevcut olan bir Bizans dönemi mezar yapısı ile aynı yerde daha sonraki dönemlerde yapılmış bir derviş türbesinin etkili olduğu ileri sürülmektedir ${ }^{68}$. Anlaşılıyor ki, üst üste eski mezar yapılarının olduğu, mezar alanı olarak belirlenmiş bu sınırlı alan Huand Hatun Türbesi’nin oldukça yüksek tutulan ve mermerle kaplanarak beş sıra mukarnas dizisiyle hareketlendirilen kaidesi ile çözümlenmiştir.

Mahperi Huand Hatun Medresesi açık avlulu, iki eyvanlı ve tek katlıdır (Plan 6a). Medresede avlunun doğu kanadındaki ana eyvanın güneyine bitişik üç bölüntülü mekânın güneydoğu köşesindeki biriminden girilen türbe kare kaideli, içten ve dıştan sekizgen planlı, içten kubbe, dıştan sekizgen piramidal külahla örtülü ve tek katlıdır ${ }^{69}$. Yapının sütuncelerle sınırlandırılan cepheleri iki kademeli sivri kemerlerle oluşturulan yüzeysel nişlerle hareketlendirilmiştir. Ayrıca cephelerde sivri kemerle kuşatılan bir sütuna atılan ikiz sivri kemerli pencereler yer alır. Türbenin gövdesinin üst/külahın alt kısmı mukarnas dizileriyle sonlanarak,

100-112; Şaman Doğan, “Kayseri Selçuklu Külliye...”, ss. 202-208; Şaman Doğan, “Kayseri Kadın Türbe...”, ss. $15-26$.

67 Kayseri Mahperi Hatun Türbesi için bkz. A Egemen, "Kayseri'de Huand Hatun Türbesi", Yapr Teknik, III/19 (1959), s. 4; Mahmut Akok, "Kayseri Hunad Külliye...", ss. 8-9; Bakırer, Anadolu Mihraplar, ss. 170-171, 294; Karamağaral,, “Kayseri'deki Hunad Câmii...”, ss. 216, 224-228, 243-245; Halil Edhem/Eldem, Kayseri Şehri, Haz. Kemal Göde, Kültür ve Turizm Bakanlığı, Ankara 1982 Yayınları, ss. 91-97; Tuncer, Kümbetler I, ss. 164-172; Önkal, a.g.e.,ss. 120-126; Durukan, "Selçuklu Kadnn Baniler...”, ss. 16-18; Kerim Türkmen, "Selçuklu Döneminde Kayseri'nin İmar Faaliyetine Katkıda Bulunan Hanımlar”, II. Kayseri ve Yöresi Tarih Sempozyumu 16-17 Nisan 1998 Kayseri, Bildiriler, Erciyes Üniversitesi Yayınları, Kayseri 1998, s. 441; Kerim Türkmen, "Kayseri Selçuklu Dönemi Yapılarında Yer Alan Ayet ve Hadisler", Zafer Bayburtluoğlu Armağanı, Sanat Yazılan, Ed. Mustafa Denktaş-Yıldıray Özbek, Kayseri Büyükşehir Belediyesi Yayınları, Kayseri 2001, s. 576; Emine Uyumaz, "Türkiye Selçuklu Sultanları, Melikleri ve Melikelerinin Evlilikleri”, I. Uluslararası Selçuklu Kültür ve Medeniyeti Kongresi, 11-13 Ekim 2000, Bildiriler II, Selçuklu Araştırmaları Merkezi Yayınları, Konya 2001, ss. 408-410, 414; Yıldıray Özbek, "Women's Tombs in Kayseri/Kayseri'deki Kadın Türbeleri”, Kadın Araştırmalan Dergisi/Gournal of Woman Studies, III/1 (2002), ss. 67-71, 88-91; Önkal, a.g.e., ss. 357358; Şaman Doğan, "Kayseri Kadın Türbe...", ss. 18-20.

${ }^{68}$ Karamağaralı, "Kayseri'deki Hunad Câmii...”, s. 209.

69 Yapının alt katının olup olmadığı kesin olarak anlaşılamamaktadır. Orhan Cezmi Tuncer, yapının alt katına bugünkü merdivenlerin altında yer alan bir kapıdan girilmesi gerektiğini ve bunun da mümkün olamayacağını belirtmektedir. Bkz. Tuncer, Kümbetler I, ss. 169-170. 
sütuncelerin kaide, gövde ve başlı̆̆ı, kemerlerin yüzeyi ve köşelikleri geometrik motiflerle süslenmiştir. Türbenin ziyaret mekânına/mescidine kuzey cephesi eksenine rastlayan medresenin güneydoğu köşe odasından çıkılan merdivenlerle ulaşılan kapıdan girilmesi, giriş ile aynı eksende (dikey eksende) bulunan beş cepheli ve beş sıra mukarnas kavsaralı anıtsal mihrabı vurgulamaktadır ${ }^{70}$. Mihrabı geometrik bezemeli iki bordür kuşatmaktadır. Yapının içinde üç sanduka vardır. Sandukalardan biri Mahperi Huand Hatuna, diğeri torunu Selçukî Hatun'a aittir. Üçüncü sandukanın kime ait olduğu bilinmemektedir. Selçuk Hatun'un sandukasındaki kitabe 1284 tarihini vermektedir ${ }^{71}$. Türbenin kaidesinde mermer, cephelerinde, duvarlarında, mihrapta ve örtü sisteminde düzgün kesme taş kullanılmıştır.

Mahperi Huand Hatun Medresesi ve Türbesi'nin inşa kitabesi yoktur. Araştırmacılardan Haluk Karamağaralı, medresenin camiden önce yaptırıldığını belirtmektedir ${ }^{72}$. Türbenin içinde olduğu Huand Hatun Camii, doğu ve batı taç kapılarında bulunan inşa kitabesine göre 635 H. /1238 M. yılında I. Alâeddin Keykubad'ın Hıristiyan eşi Mahperi Hatun tarafindan yaptırılmıştır. Caminin doğu ve batı taç kapıları üzerindeki üç satırlık kitabede "... Keyhüsrev devrinde 635 ynlında büyük Melike din ve dünyann yüz ak Mahperi Hatun emretti..." yazıları okunmaktadır ${ }^{73}$. Bu kitabelere göre caminin Keykubad'ın oğlu II. Gryaseddin Keyhüsrev devrinde, annesi Melike/Mahperi Hatun tarafindan inşa ettirildiği yazılıdır. Ayrıca türbede bulunan Mahperi Hatun'un sandukasında yer alan sülüsle yazılmış üç satırlık kitabede Keykubad oğlu II. Gıyaseddin Keyhüsrev şehit ve merhum olarak verilmiştir ${ }^{74}$. Ayrıca tarih içermeyen kitabede bani Mahperi Hatun'un '....seyyide, saide, setire, şehide, zahide, abide, ibadet etmeye düskün, mücahide, günahlardan korunmuş adalet sahibi, dünyada kadınlarn melikesi, melike, afife, temiz, devrinin Meryem'i ve zamann Hatice'si, sayssz mal tasadduku ile bilinen, din ve dünyanın saf hantm, merhum ve şehid Gyaseddin Keyhüsrev bin Keykubad'in annesi Mahperi Hatun'undur..." şeklinde abartılı şekilde övüldüğü, devrinin Meryem’i ve zamanının Hatice'si tanımlaması ile önceden Hıristiyan, sonradan Müslüman olduğuna ve zengin bir kadın kimliğine gönderme yapılmaktadır ${ }^{75}$. Kitabede Mahperi Hatun'un 1246

70 Bakırer, Anadolu Mihraplan, ss. 170-171, 294, Şek. 40, Res. 95-97.

71 Tuncer, Kümbetler I, s. 167; Önkal, a.g.e., ss.124-125.

72 Karamağaralı, "Kayseri'deki Hunad Câmii...", ss. 199-245.

73 Karamağaral,, "Kayseri'deki Hunad Câmii...”, ss. 211-216; Halil Edhem/Eldem, Kayseri Şehri, ss. 8990; Albert Gabriel, Kayseri Türk Antlan, s. 105.

74 Tuncer, Kümbetler I, s. 164-172; Önkal, a.g.e., ss.124-125.

75 Önkal, a.g.e., ss. 124. 
yılında ölen oğlu dönemin Sultanı II. Gryaseddin Keyhüsrev'den şehit ve merhum olarak söz edilmesi ile dönem kaynağı İbn Bibi’nin anlatılarında Selçuklu devlet adamı Celaleddin Karatay’ın 1254 tarihinde öldüğü zaman Mahperi Hatun’un hayatta olduğunu belirtmesi önemlidir ${ }^{76}$. Bu veriler ve yapının mimari özellikleri dikkate alındığında türbenin 1254 yılı sonrasında inşa edilmiş olabileceği anlaşılmaktadır ${ }^{77}$.

Huand Hatun Türbesi'nin banisi Selçuklu sultanı I. Alaeddin Keykubad'ın Hırıstiyan olan ilk eşi, Alanya Ermeni Kralı Kyr Vart'ın kızıdır. Alanya'nın Selçuklu Sultanı I. Alaeddin Keykubad (1220-1237) tarafindan 1221 yılındaki fethi, Keykubad'ın şehrin yöneticisi Kyr Vart'ın kızı/Mahperi Hatun ile evlenmesi (kız alışverişi) yolu ile gerçekleşmiştir. Bazı araştırmacılar Mahperi Hatun’un Yunan kökenli olma olasılığını tartışmaktadır. Mahperi Hatun'un Keykubad'ın ölümünden sonra Müslüman olduğu ve Kayseri'deki bu külliyeyi inşa ettirdiği görülmektedir ${ }^{78}$.

Çay Ebû'l-Mücahid Yusuf Bin Yakub/Taş Medresesi'nde ön/kuzey cephenin batı, batı cephenin kuzey köşesine dıştan bitişik iki katlı türbe yer alır (Fotoğraf 13-14). Medrese kapalı avlulu, iki eyvanlı ve tek katlıdır ${ }^{79}$. Yapının kuzey/ ön cephesinde eksende taç kapı, kuzeydoğu köşede çeşme ve kuzeybatı köşede türbe bulunur (Plan 6b). Türbenin alt katı/mezar odası kare planlı ve çapraz tonoz örtülü, üst katı/ziyaret mekânı/mescidi kare planlı ve üzeri üçgen kuşakla

76 İbn Bibi, El Evamirü'l-Ala'ive Fi’l-Umuri'l-Ala’iye (Selçk Name) II, Haz. Mürsel Öztürk, Kültür Bakanlı̆̆ı Yayınları, Ankara 1996, s. 136.

77 Karamağaral,, “Kayseri'deki Hunad Câmii...”, s. 216; Önkal, a.g.e., ss. 125.

78 İbn Bibi, a.g.e., ss. 258-271; Osman Turan, Selçuklular Zamanında Türkiye Siyasî Tarih Alp Arslan'dan Osman Gâzi’ye (1071-1318), Ötüken Yayınları, 8.bs., İstanbul 2004, ss. 352-360; Emine Uyumaz, "Türkiye Selçuklu Sultanları, Melikleri ve Melikelerinin Evlilikleri”, I. Uluslararası Selçuklu Kültür ve Medeniyeti Kongresi, 11-13 Ekim 2000, Bildiriler II, Selçuklu Araştırmaları Merkezi Yayınları, Konya 2001, ss. 409-411; Emine Uyumaz, Sultan I. Alâeddîn Keykubad Devri Türkiye Selçuklu Devleti Siyasî Tarihi (1220-1237), Türk Tarih Kurumu Yayınları, Ankara 2003, ss. 23-24; Emine Uyumaz, "Sultan I. Alaeddin Keykubad ve Zamanı", Anadolu Selçuklulan ve Beylikler Dönemi Uygarlığ 1, Ed. Ahmet Yaşar Ocak, Kültür ve Turizm Bakanlığı Yayınları, Ankara 2006, ss. 108-109; Scott Redford- Gary Leiser, Taşa Yazılan Zafer Antalya İçkale Surlanndaki Selçuklu Fetihnâmesi, Suna-İnan Kıraç Akdeniz Medeniyetleri Araştırma Enstitüsü Yayınları, Antalya 2008, s. 19; Muhammet Kemaloğlu, "Türkiye Selçuklularında Gayr-1 Müslim Tebaa ile Kurulan Sosyal İlişkiler", Mehmet Akif Ersoy Üniversitesi Sosyal Bilimler Enstitüsü Dergisi, 7 (2012), s. 176; İsmail Çiftçioğlu, "Anadolu Selçuklu Sultanlarının Gayrimüslim Kadınlarla Evlilikleri”, Zeitschrift für die Welt der Türken, 5 (2013), ss. 13-14. Rüstem Şükürov, "Harem Hıristiyanlığı: Anadolu Selçukluları'nın Bizans Kimliğì, Çev. Eda Havva Tan, Yay. Haz. İvan Pavli-Badegül Can Emir, Türk Bizans Illiskileri ve Anadolu'nun Türkleşme Süreci, Kültür Bilimleri Akademisi Yayınlar1, İstanbul 2016, ss. 136-139, 144-146.

${ }_{79}$ Kuran, Medreseler, ss. 57-59; Sözen, Anadolu Medreseleri II, ss. 75-79; Önkal, a.g.e., ss. 275-279; Özkarc1, a.g.e., ss. $40-45$. 
geçilen kubbe ile örtülüdür. Kübik gövdesi ve kubbesiyle dışa yansıyan türbenin alt ve üst katına avlunun kuzeybatı köşesindeki kuzey-güney yönünde dikdörtgen planlı mekânının kuzey ve batı duvarlarındaki merdivenlerle ulaşılan kapıdan girilmektedir. Türbenin ziyaret mekânı/mescidi kuzey duvarındaki iki dikdörtgen pencere ile dışa, doğu duvarındaki basık kemerli bir kapıyla kuzeybatı köşe odasına açılmaktadır. Ayrıca mescidin güney duvarı ekseninde özgününde yarım daire nişli bir mihrap bulunur. Bugün sözü edilen mihrap ocak nişine dönüştürülmüştür ${ }^{80}$. Türbede sanduka yoktur. Yapıda cephelerde ve duvarlarda düzgün kesme taş, kubbeye geçiş ve kubbede firuze renkli sırlı-sırsız tuğla kullanımı görülür ${ }^{81}$. Türbenin kuzey cephesinde ön cepheye yansiyan dikdörtgen pencerelerin üst bölümü üç sıra mukarnas dizisi ile sonlanarak, dıştan yüzeyi geometrik motiflerle süslenmiş, içten bezemesiz iki bordürle üç yönden çevrilmiştir. Bezemeli bordürün alt kısmı tahrip olmuştur. Türbenin kubbesinde firuze renkli sırlı tuğlaların dikey, sırsız tuğlaların yatay uygulanmasıyla zikzak motifleri oluşturulmuştur ${ }^{82}$.

Çay Ebû'l-Mücahid Yusuf Bin Yakub türbesinin kitabesi bulunmamaktadır. Bitişiğindeki medreseyle organik bir bütünlük gösteren türbenin medreseyle eş zamanlı yapıldığı anlaşılmaktadır. Medrese taç kapısı üzerindeki sülüsle yazılmış iki satırlık inşa kitabesine göre Ebû'l-Mücahid Yusuf Bin Yakub tarafindan 12781279 yılında, mimar Oğulbek bin Mehmed'e yaptırılmıştır ${ }^{83}$.

Medresenin ve türbenin banisi Ebû'l-Mücahid Yusuf Bin Yakub hakkında bilgilerimiz sınırlıdır. Ebû'l-Mücahid (mücahitlerin babası) ününü kullanan Yusuf Bin Yakub’un III. Gryaseddin Keyhüsrev (1266-1284) döneminde büyük komutan ve devlet adamı olduğu anlaşılmaktadır ${ }^{84}$.

\section{Değerlendirme}

İncelenen örneklerde görüldüğü gibi 13. Yüzyılda/Anadolu Selçuklu döneminde medrese ve darüşşifaların çoğunda yapı kütlesi içinde eyvanlardan birine bitişik mekân türbe olarak tasarlanmıştır. Medreselerde açık ya da kapalı bir avlunun yatay ve dikey eksenlerine yerleştirilen eyvanlar, avlu zemininden

\footnotetext{
80 Özkarc1, a.ge., ss. 43-44.

${ }_{81}$ Bakırer, Selçuklu Tuğga Kullanmm I, ss. 462-465; Özkarc1, a.g.e., ss. 62; Arık, "Anadolu Selçuklu Toplum Hayatinda Çini", ss. 66.

82 Önkal, a.g.e., ss. 277; Özkarc1, a.ge.,ss. 44-45, 62, 65, Res. 29-30; Arık, "Anadolu Selçuklu Toplum Hayatinda Çini”, ss. 66; Arık, "Anadolu Selçuklu ve Beylikler Dönemi Dini ve Kamusal Yapılarnda Çini”, ss. 146-150.

83 Bayburtluoğlu, a.g.e., ss. 152-153; Sönmez, a.g.e., 1995, ss. 303-308; Özkarc1, a.g.e., ss. 34-37,40; Önkal, a.g.e., s. 278.

${ }_{84}$ Özkarc1, a.g.e., ss. 67-68; Önkal, a.g.e., s. 278.
} 
ve beden duvarlarından yüksek tutulan, açık ve kapalı mekân özelliği yansıtan yönlendirici ve hareketli birimlerdir. Özellikle diğer eyvanlardan geniş, derin ve yüksek olan ana eyvan, medrese ve darüşşifaların avlusunu çevreleyen birimlere hakim konumdadır. Bu bağlamda medreselerde kurgu ve süslemeleri ile öne çıkan eyvanlara türbelerin bitişik planlanması, türbelerin de görünür olmasını ve vurgulanmasını sağlamaktadır. Medreselerde türbelerin yeri eyvan sayısı ve mescidin konumuna bağlı olarak değişiklik göstermektedir. Yapıların içindeki bu türbeler medresede okuyan öğrenciler ve çalışan personel tarafindan ziyaret yapılan ve dua edilen önemli mekânlardır.

Anadolu Selçuklu döneminde medrese mimarisi iki koldan (Danişmentli, Artuklu) gelişimini sürdürmüştür. Kapalı avlulu medreselerin ilk örnekleri Danişmentli kültür çevresinde Tokat ve Niksar'da, açık avlulu medreselerin ilk örnekleri Artuklu kültür çevresinde Diyarbakır, Mardin, Urfa gibi yerleşimler ve çevresinde karşımıza çıkmaktadır ${ }^{85}$. Kapalı avlulu olan Tokat (1142-1164) ve Niksar Yağıbasan/Çukur (1157) medreselerinin içinde ya da bitişiğinde türbe işlevli bir mekânın varlığı tartışmalıdır ${ }^{86}$. Özellikle Niksar Yağıbasan Medresesi’nin büyük ölçüde yıkılmış olması, yapının avlusunu çevreleyen mekânların tümüyle algılanmasını, türbe gibi özel işlevli birimlerin tespitini zorlaştırmaktadır.

Açık avlulu medreselerde çoğunlukla simetrik, bazı örneklerde asimetrik kurgulanan eyvan şeması yaygındır. Artuklu yapılarında erken tarihli örneklerden başlayarak bu eyvanlara içten ya da dıştan bitişik kare planlı mekânlar türbe olarak yapılmıştır. Örnek olarak Mardin Hatuniye/Sitti Radviyye Medresesi'nde (11771185) ana eyvanın doğusuna bitişik, Diyarbakır Zinciriye/Sincariye Medresesi'nde (1198-1199) güneydeki ana eyvan ile aynı yöndeki güneydoğu köşe mekânı kare planlı, üzeri tromplarla geçilen kubbeyle örtülü, Mardin Şehidiye Medresesi'nde (13.Yüzyılın ortaları) ise avlunun güneyindeki caminin doğusuna bitişik/güneydoğu köşedeki dikdörtgen planlı ve sivri tonoz örtülü mekân, yapıya adını veren kırk şehitlerin yattı̆ğ türbe olarak inşa edilmiştir ${ }^{87}$. Artuklu örneklerinde türbenin en

${ }^{85}$ Kuran, Medreseler, ss. 15-39; Ara Altun, Anadolu'da Artuklu Devri Türk Mimarisinin Gelişmesi, Kültür Bakanlığ̣ Yayınları, İstanbul 1978, ss. 115-183, 275-277; Aynur Durukan, "Artuklu Mimarisinin Düşündürdükleri”, Dokuzuncu Milletlerarası Türk Sanatlan Kongresi, 23-27 Eylül 1991 Istanbul, Bildiriler, II. Kültür Bakanlığ1 Yayınları, Ankara 1995, ss. 51-62.

${ }^{86}$ Abdullah Kuran, "Tokat ve Niksar'da Yağı-Basan Medreseleri”, Vakıflar Dergisi, 7 (1968), ss. 39-43; Kuran, Medreseler, ss. 20.

${ }^{87}$ Figen Ilter, "Erken Devir Anadolu Türk Mimarisinde 12. ve 13. Yüzyll Artukoğulları Medreselerinin Yeri”, Vakuflar Dergisi, 8 (1969), ss. 202-207; Kuran, Medreseler, ss. 28-30, 33-36; Altun, Artuklu Deori, ss. 115-129, 152-160 
vurgulu olduğu yapı Mardin Sultan İsa/Zinciriye Medresesi (1385)'dir. Doğubatı doğrultusunda dikdörtgen planlı medresenin içinde güneydoğu köşe camiye, güneybatı köşe kare planlı, tromplarla geçilen kubbe ile örtülü türbeye ayrılarak hem caminin, hem de türbenin aynı yöndeki vurgusu artırılmıştır. Medresenin içindeki cami ve türbe dikdörtgen payandalarla desteklenen yivli kubbelerle dışa yansımaktadır $^{88}$. Artuklu medreselerinin içinde yer alan tek katl türbeler, tek kat örtü sistemine sahiptir. Bu örneklerde bazı Selçuklu medreselerinin içindeki türbelerde olduğu gibi dıştan piramidal ya da konik külahla örtülü uygulamalara rastlanmamaktadır.

Medreselerin içinde yer alan türbelerin alt katları/mezar odaları çoğunlukla kare ya da dikdörtgen planlı ve sivri tonoz örtülü, üst katları/ziyaret mekânı/ mescidi genellikle kare, bazıları dikdörtgen, çok az örnekte çokgen/sekizgen planlı, içten kubbe, dıştan sekizgen piramidal külahla örtülüdür. Kayseri'deki Çifte/Gevher Nesibe Medresesi Türbesi'nin üst katı/ziyaret odası dıştan kareye yakın dikdörtgen, içten yarım daire nişlerle genişletilmiş sekizgen planlı, içten kubbe dıştan sekizgen piramidal külahla örtülü farklı bir örnektir.

13. yüzyılın ikinci yarısında (1250 yllı sonrasında) İlhanlıların Anadolu'da etkili olduğu yıllarda yaptırılan bazı örneklerde medrese kütlesi dışında, ana eyvanın arka cephesine veya cephelerden birine bitişik türbe inşa edilmiştir. Illhanlı döneminde Erzurum'daki Çifte Minareli/Hatuniye ve Yakutiye medreseleri çifte minareli kurguları ve ana eyvanın arka cephesine bitişik türbeleri ile dönemin en anıtsal örnekleridir ${ }^{39}$. Bu medreselerde ön cephelerde çifte minareli taç kapılarla oluşturulan düşeylik/yükseklik etkisi, arka cephelerde türbelerin bitişik yapılmasıyla artırılmışır. Selçuklu dönemi bağımsız türbeleri gibi kaide, gövde ve külahıyla dışa yansıyan bu türbelere medresenin içindeki eyvan ya da eyvanın bitişiğinde bulunan diğer mekânlardaki kapılarla girilmekte veya bağlantı pencerelerle sağlanmaktadır. Örneklerde türbelerin dıştan bitişik olması; türbenin çevreyle bağlantısını artırmakta, sadece medresede okuyan ve çalışanların değil, yapıların önünden ya da yakınından gelip geçen halktan kişilerin de ziyaret ve dua etmesini kolaylaştırmaktadır.

Selçuklu mimarisinde 13. yüzyılın ortalarından başlayarak medreselerdeki türbe ve mescitlerin dıştan bitişik yapılması, dışarıya alınması, benzer şekilde camilere bitişik türbelerin inşasında da yinelenmiştir. Söz konusu dönemdeki

88 Altun, Artuklu Devri, ss. 170-183.

89 Tuncer, Moğollar, ss. 26-28, 33-34. 
benzer uygulamalarda "medrese-türbe, medrese-mescit, cami-türbe" bitişiklikleri karşımıza çıkmaktadır. Medreseye bitișik mescitlere Akșehir Taș (1250) ve Konya Ince Minareli (1264) medreselerini, camiye bitişik türbelere Amasya'daki Burmalı Minare (1247) ve Gök Medrese (1267), Beyşehir Eşrefoğlu (1296-1299) ve Niğde Sungur Bey (1335) camilerini örnek verebiliriz. Camilere bitişik türbelerden üç örnekte yapıların doğu cephesine, Amasya Burmalı Minare Camii’nde ise farklı olarak kuzey cephenin doğu köşesine bitişik türbe yer alır ${ }^{90}$. Burmalı örneğinde caminin ön/kuzey cephesinde eksende taç kapı, doğu köşede türbe, batı köşede minarenin olması ön cephe vurgusunu artırmıştır. Bir başka deyişle, türbenin bağlı olduğu medrese ya da caminin dışına alınması baninin kimliğini vurgulamakta, dikey/düşey kurgusuyla daha çok ilgi çekmesine yol açmaktadır.

Aynı zaman diliminde Anadolu dışındaki komşu kültür çevrelerindeki, özellikle Suriye ve Mısır'da hüküm süren Eyyubi ve Memluk dönemleri medreselerinde çoğunlukla "medrese-türbe" ya da "medrese-mescit-türbe" tasarımının birlikteliği görülür. Anadolu'daki örneklerde uygulandığı gibi genellikle medreselerin içinde ya da dıştan bitişiğinde, bani ya da yakınlarının türbeleri bulunmaktadır ${ }^{91}$. Anadolu örneklerinden farklı olarak Suriye/Şam ve Mısır/Kahire medreselerinin anıtsal kurgulanan türbeleri, kare planlı, yüksek kasnağa oturan sivri kubbeleri ve bezemeleri ile öne çıkarak daha güçlü bir şekilde vurgulanmıştır. Bu grup içinde Şam'daki Rükniyyet'ül-Berrâniyye (1224-1227), Eşrefiyye/Cevvâniyye ve Berrâniyye (1232-1237), Atabekiyye (1242), Zâhiriyye (1277-1281), Kahire'deki Necmeddin Salih Eyyub (1243-1244)ve Sultan Hassan(1356-1363) medreselerinin türbelerini sayabiliriz ${ }^{92}$.

Örneklerde okunduğu gibi Orta ve Doğu Anadolu'daki Konya, Kayseri, Kırşehir, Sivas ve Erzurum gibi merkezlerde bulunan kapalı ya da açık avlulu

90 Kuran, Medreseler, ss. 54-55, 79-82; Tuncer, Moğollar, ss. 10-11, 29-31, 35-36; Erdemir Yaşar, Beyşehir Eşrefoğlu Süleyman Bey Camii ve Külliyesi, Beyşehir Vakfi Yayınları, Beyşehir 1999, ss. 20-35; Yaşar Erdemir, Ince Minareli Medrese Taş ve Ahşap Eserler Müzesi, Konya Valiliği İl Kültür ve Turizm Müdürlüğ̈ Yayınları, Konya 2007, ss. 97, 100-101.

${ }_{91} \mathrm{Bu}$ medreseler için bkz. Michael Meinecke, Die Mamlukische Architektur in Ägypten und Syrien: (648/1250-923/1517 I, Abhandlungen des Deutschen Archäologischen Instituts, Kairo 1992, ss. 37-40, 54, 77-80,123-129, 144,156, 158-159; Michael Rogers, "Mısır'ın Başşehri Kahire IV. Mimari”, Türkiye Diyanet Vakfi Íslam Ansiklopedisi, 24 (2001), ss. 182-191; Ahmet Ali Bayhan, "Misır'daki Eyyubi Devri Mimari Eserleri: Medreseler ve Hankâh/Zaviyeler", Atatürk Üniversitesi Güzel Sanatlar Enstitüsü Dergisi, 12 (2004), ss. 1-16; Ahmet Ali Bayhan, "Mısır'daki Eyyubi Devri Mimari Eserleri: Türbeler”, Atatürk Üniversitesi Güzel Sanatlar Enstitüsü Dergisi, 13, (2004b), ss. 21-41; Abdülselam Uluçam, "Şam, IV. Mimari", Türkiye Diyanet Vakfi İslam Ansiklopedisi, 38, (2010), ss. 320-325.

92 Meinecke, a.g.e., ss. 37-39, 54-55, 77; 123-126; Rogers, a.g.m., ss. 186-187; Bayhan, "Eyyubi Medreseler...”, ss. 6-8, 13; Bayhan, “Eyyubi Türbeler...”, ss. 26-27, 37, 40; Uluçam, a.g.m., ss. 320-321. 
medreselerde "medrese-türbe (eyvan-türbe)" ilişkisi ortak özellikler yansitmaktadır. Güneydoğu Anadolu'daki Diyarbakır, Mardin, Urfa gibi yerleşimlerde yer alan çoğunluğu açık avlulu olan medreselerdeki "medrese-türbe" ilişkisi daha çok komşu kültür çevrelerinde Suriye ve Mısır'daki Eyyubi -Memluklu medreseleri ile benzerlik göstermektedir.

Selçuklu dönemini izleyen Anadolu Beylikleri (14-15.yüzyll) devri kentlerdeki imar faaliyetleri açısından yeni arayışlar, farklı gelişmeler gösteren devingen bir ortam sergilemektedir. Beylikler döneminde (Erken Osmanlı Beyliği dışında) inşa edilmiş çoğunluğu açık avlulu olan medreselerde örneklerimizle paralellik gösteren içte eyvanlardan birine bitişik, eyvanda ya da yapılara diştan bitişik türbelerin varlığı bu uygulamanın devamlılığını göstermektedir. Karamanoğulları dönemi yapılarından Ermenek Emir Musa/Tol Medresesi’nde (1339) ana ve yan eyvana, Karaman Hatuniye/Nefise Melek Hatun Medresesi'nde (1381-1382) ana eyvana, Saruhanoğulları Beyliği dönemine ait Manisa Ulu Camii/İshak Çelebi Medresesi’nde (1378) yan eyvana bitişik, Menteşeoğluları Beyliği örneği Peçin Ahmet Gazi Medresesi'nde (1375) ana eyvanda, Karaman İbrahim Bey Imareti Medresesi'nde (1431-1432) ise batı cephenin güney köşesine bitişik türbeler yer alır $^{93}$. Buna karşılık, Erken Osmanlı döneminde medreselerin içinde ve bitişiğinde türbe inşa edilmediği görülmektedirr ${ }^{94}$.

\section{Sonuç}

Anadolu Selçuklu ve İlhanlı dönemlerinde inşa edilen külliyeler/yapı toplulukları incelendiğinde genellikle farklı işlevli yapılar bitişik kurgulanmıştır. Örnekler "darüsssifa-medrese-türbe", "cami-medrese -türbe-hamam", "cami-türbe-hanikâh", "cami-türbe" ve "medrese-türbe" olmak üzere çeşitlilik göstermektedir.

93 Ernst Diez-Oktay Aslanapa-Mahmut Mesut Koman, Karaman Devri Sanat, İstanbul Üniversitesi Edebiyat Fakültesi Yayınları, İstanbul 1950, ss. 19-27, 55-85; Abdullah Kuran, "Karamanl Medreseleri", Vakıflar Dergisi, 8 (1969), ss. 21 1-212, 216-217, Şek. 1,6, Res.1-5, 20-25; Y1lmaz Önge, "Konya Ermenek'te Karamanoğlu Emir Musa Medresesi (Tol Medrese)", Önasya, 5 (1969), s. 51; Sözen, Anadolu Medreseleri I, ss. 131-134, 140-144, 179-187; Sözen, Anadolu Medreseleri II, ss. 34-41; Hakkı Acun, "Manisa İshak Çelebi Külliyesi”, Vakuflar Dergisi, 19 (1985), s. 127-146; Z. Kenan Bilici, "Karaman'da İbrahim Bey İmareti'ne Bitişik Türbe ve Tarihlendirilmesi Problemi”, X. Türk Tarih Kongresi, 22-26 Eylül 1986, Bildiriler, V (1994), ss. 2337-2347; Hakkı Acun, Manisa'da Türk Devri Yapılan, Türk Tarih Kurumu Yayınları, Ankara 1999, ss. 310-319, 396-399; İsmail Çiftçioğlu, "Ermenek’te Emir Musa Bey Medresesi (Tol Medrese) ve Vakfiyesi”, İlmi Araştrrmalar, 12 (2001), ss. 73-82; Enis Karakaya, "Menteşeoğulları (Mimari)", Türkiye Diyanet Vakfi Islam Ansiklopedisi, 29 (2004), ss. 152-153; Osman Nuri Dülgerler, Karamanoğullan Dönemi Mimarisi, Türk Tarih Kurumu Yayınları, Ankara 2006, ss.106-109, 112-113.

94 Demiralp, Osmanl Medreseleri, ss. 226-228; Demiralp, “Medreselerde Örtü...”, ss. 38-39. 
Bu çerçevede medreseler ve darüşşifalar özelinde düşünüldüğünde, yapılarda avlu çevresindeki mekân tasarımında içteki ve yapıların bitişiğindeki türbelerin varlı̆̆ı, dönemin genel anlayışını yansıtmaktadır. Yukarıda sözü edilen Orta Çă̆ Türk mimarisinde bitişik kurgulu yapı topluluklarının, medreselerdeki mekânsal düzenlemede de etkileri görülmektedir. Medreselerdeki bani türbelerinin planlamasında hem iç içelik, hem de bitişiklik ilkesi dikkati çekmektedir. Aynı düzenleme medrese-mescit uygulamalarında da yinelenmiştir.

Anadolu'da Selçuklu, İlhanlı ve Beylikler dönemi medreselerinin çoğunda bani türbeleri yapıların içindeki bir mekânda ya da bazı örneklerde yapılara dıştan bitişik inşa edilmiştir. Buna karşılık Erken Osmanlı Beyliği’nden başlayarak Osmanlı döneminde inşa edilen medreselerin içinde bani türbeleri için ayrılmış özel mekânlar bulunmamaktadır. Bu medreselerin plan tiplerinde kare ya da dikdörtgen planlı açık avluların çevresinde dizili mekânların yanı sıra, U ve L şemalı gibi uygulamalar, değişimler, yenilikler de ortaya çıkmaktadır. Osmanlı döneminde çoğunlukla külliyelerin/yapı topluluklarının serbest tasarlandı̆̆ı medreselerin, türbelerin ve diğer yapıların bağımsız inşa edildiği görülür. Örneklerde bağımsız inşa edilen bu türbeler mimarisi ve süslemeleri ile öne çıkan anıtsal yapılardır. Külliye içinde ya da bağımsız inşa edilen Osmanlı dönemi türbeleri plan şeması, mimari ögeleri, malzeme-teknik ve süsleme özellikleri ile dönem üslubunu yansıtan önemli örnekler olarak karşımıza çıkmaktadır.

\section{KAYNAKLAR}

Acun, Hakkı, "Manisa İshak Çelebi Külliyesi”, Vakıflar Dergisi, 19 (1985), ss. 127-146. , Manisa'da Türk Devri Yapılan, Türk Tarih Kurumu Yayınları, Ankara 1999.

Akçay, İlhan, "Yakutiye Medresesi", Vakıflar Dergisi, 6 (1966), ss. 146-152.

Akok, Mahmut, "Kayseri'de Hunad Mimari Külliyesinin Rölövesi”, Türk Arkeoloji Dergisi, XVI/1 (1967), ss. 5-44.

, "Kayseri'de Gevher Nesibe Sultan Darüşşifası ve Sahabiye Medresesi

Rölöve ve Mimarisi”, Türk Arkeoloji Dergisi, 17/1(1968), ss. 133-184.

, "Konya'da Sirçalı Medresenin Rölöve ve Mimarisi", Türk Arkeoloji Dergisi, 18/1 (1969), ss. 5-35.

, "Konya'da Karatay Medresesi Rölöve ve Mimarisi”, Türk Arkeoloji

Dergisi, 18/2 (1970), ss. 5-28. 
"Konya-Akşehir'de Taş Medrese Binası ve Restorasyon Çalışmaları", Türk Etnoğrafya Dergisi, 26 (1977), ss. 5-26.

Aksulu, Işık, "Bir Selçuklu Mirası Beşiği-Tokat Kenti", I. Uluslararası Selçuklu Kültür ve Medeniyeti Kongresi, 11-13 Ekim 2000, Bildiriler I, Selçuklu Araştırmaları Merkezi Yayınları, Konya 2001, ss. 1-17, 487-502.

Altun, Ara, Anadolu'da Artuklu Devri Türk Mimarisinin Gelişmesi, Kültür Bakanlığı Yayınları, İstanbul 1978.

239.

, "Çay Medresesi", Türkiye Diyanet Vakfi İslam Ansiklopedisi, 8 (1993), s.

Arel, Ayda, "Menteşe Beyliği Devrinde Peçin Şehri, Anadolu Sanatı Araştırmalar, I (1968), ss. 69-98.

Arık, Oluş M. "Erken Devir Anadolu-Türk Mimarisinde Türbe Biçimleri, Anadolu (Anatolia), 11 (1967), ss. 57-100.

, "Anadolu Selçuklu ve Beylikler Dönemi Dini ve Kamusal Yapılarında Çini”, Anadolu Toprağının Hazinesi Çini Selçuklu ve Beylikler Çağı Çinileri, Ed. Rüçhan Arık-Oluş Arık, Kale Grubu Kültür Yayınları, İstanbul 2007, ss..37-189.

"Anadolu Selçuklu Toplum Hayatında Çini". Anadolu'da Türk Devri Çini ve Seramik Sanatı, Ed. Gönül Öney-Zehra Çobanlı, Kültür ve Turizm Bakanlığı Yayınları, İstanbul 2007, ss. 29-69.

Arıkan, Nihat-Tuğutlu Eylem-Eraslan Yıldız, Kirşehir Emiri Caca Bey ve Medresesi "Simetrik Yaklaşımlar", Kırşehir Valiliği Yayınları, Kırşehir 2009.

Aslanapa, Oktay, "Selçuk Devlet Adamı Mübarizeddin Ertokuş Tarafindan Yaptırılan Abideler", İslam Tetkikleri Enstitüsü Dergisi, II/1 (1957), ss. 97-111.

Bakırer, Ömür, Onüc ve Ondördüncü Yüzyllarda Anadolu Mihraplan Türk Tarih Kurumu Yayınları, Ankara 1976.

, Selçuklu Öncesi ve Selçuklu Dönemi Anadolu Mimarisinde Tuğla Kullanımı, I, Orta Doğu Teknik Üniversitesi Yayınları, Ankara 1981.

, Selçuklu Öncesi ve Selçuklu Dönemi Anadolu Mimarisinde Tuğla Kullanımı, II, Orta Doğu Teknik Üniversitesi Yayınları, Ankara 1981.

, "Sivas Keykavus Darüşşifası'nda Taş, Tuğla ve Çini”, Aynur Durukan'a Armağan, Ed. Nermin Şaman Doğan, Renkmay Basımevi, Ankara 2002, ss. 7590.

Bayat, Ali Haydar, "Sivas Darüşşifası'nın Bilinen ve Bilinmeyen Kitabeleri”, Selçuklular Döneminde Sivas Sempozyumu Bildirileri, 29 Eylül-1 Ekim 2005, Sivas 2006, ss. 351365. 
Bayburtluoğlu, Zafer, Anadolu'da Selçuklu Dönemi Yapı Sanatçılar, Atatürk Üniversitesi Yayınları, Erzurum 1993.

Bayhan, Ahmet Ali, "Mısır'daki Eyyubi Devri Mimari Eserleri: Medreseler ve Hankâh/Zaviyeler", Atatürk Üniversitesi Güzel Sanatlar Enstitüsü Dergisi, 12, (2004), ss. 1-16.

, "Mısır'daki Eyyubi Devri Mimari Eserleri: Türbeler", Atatürk Üniversitesi Güzel Sanatlar Enstitüsü Dergisi, 13, (2004), ss. 21-41.

Baykara, Tuncer, I. Gyaseddin Keyhusrev (1164-1211) Gazi-Şehit, Türk Tarih Kurumu Yayınları, Ankara 1997.

Bilget, Burhan, I. İzzeddin Keykavus Darüsşifası, Kültür Bakanlı̆̆ı Yayınları, Ankara 1990. , Sivas’ta Buruciye Medresesi, Kültür Bakanlığı Yayınları, Ankara 1991.

Bilici, Z. Kenan, “Karaman'da İbrahim Bey İmareti’ne Bitişik Türbe ve Tarihlendirilmesi Problemi”, X. Türk Tarih Kongresi, 22-26 Eylül 1986, Bildiriler, V (1994), ss. 2337-2347.

Can, Sevim, Terken Hatun'dan Valide Sultan'a Selçuklular Döneminde Kadın (1040-1308), Ufuk Ötesi Yayınları, İstanbul 2008.

Cantay, Gönül, Anadolu Selçuklu ve Osmanl Darüsşifalan, Atatürk Kültür Merkezi Yayınları, Ankara 1992.

Cevdet, Melih, "Sivas Darüşşifası Vakfiyesi ve Tercümesi”, Vakıflar Dergisi, I, (1938), ss. 35-38.

Çam, Nusret, "Erzurum'daki Yakutiye Medresesi İle İlgili Bazı Mülahazalar”, Vakıflar Dergisi, 20 (1988), ss. 289-310.

Çayırdağ, Mehmet, "Kayseri Hunat Külliyesi”, Vakıf ve Kültür, $1 / 2$ (1998), ss. 23-26.

Çetintaş, Sedat, Sivas Darüş̧sifası 614-1217, İbrahim Horoz Basımevi, İstanbul 1953.

Çiftçioğlu, İsmail, "Ermenek’te Emir Musa Bey Medresesi (Tol Medrese) ve Vakfiyesi”, İlmi Araştırmalar, 12 (2001), ss. 73-82.

, "Anadolu Selçuklu Sultanlarının Gayrimüslim Kadınlarla Evlilikleri”, Zeitschrift für die Welt der Türken, 5 (2013), ss. 7-25

Demiralp, Yekta, Erken Dönem Osmanl Medreseleri (1300-1500), Kültür Bakanlığ1 Yayınları, Ankara 1999.

, "Osmanlı Öncesi Anadolu Medreselerinde Örtü ve Erken Osmanlı Medreseleri ile Karşılaştırma”, Sanat Tarihi Dergisi, XV/2 (2006), ss. 29-48. 
Diez, Ernst -Aslanapa Oktay -Koman Mahmut Mesut, Karaman Devri Sanatı, İstanbul

Üniversitesi Edebiyat Fakültesi Yayınları, İstanbul 1950

Duran, Remzi, Selçuklu Devri Konya Yapı Kitâbeleri (İşa ve Ta’mir), Türk Tarih Kurumu Yayınları, Ankara 2001.

, "Konya Alaeddin Camisi Kitabeleri", Anadolu Selçuklular ve Beylikler

Dönemi Uygarlğ̆ 2, Ed. Ali Uzay Peker- Kenan Bilici, Kültür ve Turizm Bakanlığı Yayınları, Ankara 2006, ss. 23-29.

Durukan, Aynur, "Artuklu Mimarisinin Düşündürdükleri”, Dokuzuncu Milletlerarası Türk Sanatlan Kongresi, 23-27 Eylül 1991 İstanbul, Bildiriler, II. Kültür Bakanlığı Yayınları, Ankara 1995, ss. 51-62.

, "Anadolu Selçuklu Sanatında Kadın Baniler", Vakıflar Dergisi, 27 (1998), ss. 15-36. , "Banîler", Anadolu Selçuklulan ve Beylikler Dönemi Uygarlĭg 2, Ed. Ali Uzay Peker- Kenan Bilici, Kültür ve Turizm Bakanlığı Yayınları, Ankara 2006, ss. $137-171$.

Dülgerler, Osman Nuri, Karamanoğullan Dönemi Mimarisi, Türk Tarih Kurumu Yayınları, Ankara 2006.

Edhem/Eldem, Halil, Kayseri Şehri, Haz. Kemal Göde, Kültür ve Turizm Bakanlığı, Ankara 1982 Yayınları.

Egemen, A., "Kayseri'de Huand Hatun Türbesi”, Yapı Teknik, III/19 (1959), s. 4.

Erdemir, Yaşar, Beyşehir Eşrefoğlu Süleyman Bey Camii ve Külliyesi, Beyşehir Vakfi Yayınları, Beyşehir 1999.

,Ince Minareli Medrese Taş ve Ahşap Eserler Müzesi, Konya Valiliği Il Kültür ve Turizm Müdürlüğü Yayınları, Konya 2007.

"Konya Alâeddin Camii'nin Avlusundaki Bitmemiş Yapının Mahiyeti Hakkında", Selçuklu'dan Osmanliya Bilim, Kültür ve Sanat Prof. Dr. Mikâil Bayram'a Armağan, Konya 2009,ss. 231-250.

, Sirçalı Medrese Mezar Antlan Müzesi Konya Valiliği İl Kültür ve Turizm Müdürlüğ̈ Yayınları, 3. bs., Konya 2015.

Karatay Medresesi Çini Eserler Müzesi Konya Valiliği İl Kültür ve Turizm Müdürlüğü Yayınları, 3. bs., Konya 2015.

Ferit, M. - Mesut, M., Selçuk Veziri Sahip Ata ile Oğullarnmn Hayat ve Eserleri. Türkiye Matbaası, İstanbul 1934. 
Gabriel, Albert, Kayseri Türk Antlan, Haz. F. Yaman, Kayseri Enstitüsü Derneği Yayınları, Kayseri 2009.

Geyikoğlu, Hasan, “Antalya'nın İlk Türk Mülki Amiri ve Kumandanı Mübarizettin Ertokuş'un Faaliyetleri ve Eserleri”, Adalya, V (2002), ss. 187-200.

Göksu, E., Türkiye Selçuklularnnda Ordu, Türk Tarih Kurumu Yayınları, Ankara 2010.

Gürbüz, Osman, "Erzurum Çifte Minareli Medrese'nin Yapım Tarihi ve Bânîsi Hakkında Yeni Bir Yaklaşım”, Atatürk Üniversitesi Türkiyat Araştırmalan Dergisi, 25 (2004). ss. 145-160.

Gürkan, K. "Selçuklu Hastaneleri”, Malazgirt Armağan, Ankara 1972, ss. 33-63.

İbn Bibi, El Evamirü'l-Ala'iye Fi'l-Umuri'l-Ala'iye (Selçuk Name) I, Haz. Mürsel Öztürk, Kültür Bakanlığı Yayınları, Ankara 1996.

El Evamirü'l-Ala’iye Fi'l-Umuri'l-Ala’iye (Selçuk Name) II, Haz. Mürsel Öztürk, Kültür Bakanlığı Yayınları, Ankara 1996.

İlter, Figen, "Erken Devir Anadolu Türk Mimarisinde 12. ve 13. Yüzyıl Artukoğulları Medreselerinin Yeri”, Vakıflar Dergisi, 8 (1969), ss. 197-208.

İpekoğlu, Başak, "Birleşik İşlevli Yapılar”, Anadolu Selçuklular ve Beylikler Dönemi Uygarllğ̆, 2, Ed. Ali Uzay Peker-Kenan Bilici, Kültür ve Turizm Bakanlığı Yayınları, Ankara 2006, ss, $111-125$.

Karakaya, Enis, "Menteşeoğulları (Mimari)", Türkiye Diyanet Vakfi İslam Ansiklopedisi, 29 (2004), ss. 152-153.

Karamağaralı, Haluk, "Erzurum'daki Hatuniye Medresesi'nin Tarihi ve Banisi Hakkında Mülâhazalar", Selçuklu Araştırmalar Dergisi, 3 (1971), ss. 209-242. , "Kayseri'deki Hunad Câmiinin Restitüsyonu ve Hunad Manzumesinin Kronolojisi Hakkında Bazı Mülâhazalar”, Ankara Üniversitesi Ilahiyat Fakültesi Dergisi, XXI (1976), ss. 199-245.

Kemaloğlu, Muhammet," Türkiye Selçuklularında Gayr-1 Müslim Tebaa ile Kurulan Sosyal İlişkiler", Mehmet Akif Ersoy Üniversitesi Sosyal Bilimler Enstitüsü Dergisi, 7 (2012), 168-185.

Kırpık, Güray-Akyol Hasan, "I. Gıyaseddin Keyhüsrev”, Selçuklu Tarihi El Kitabı, R. Turan, (Ed.), Grafiker Yayınları, Ankara 2012, ss. 347-350.

Koca, Salim, Sultan I. İzeddin Keykâvus (1211-1220), Türk Tarih Kurumu Yayınları, Ankara 1997. 
, "Gelişme Dönemi: Sultan I. İzzeddin Keykavus", Anadolu Selçuklulan

ve Beylikler Dönemi Uygarlğ̆ I, Ed. Ahmet Yaşar Ocak, Kültür ve Turizm Bakanlığı Yayınları, Ankara 2006, ss. 91-105.

Koçyiğit, Fazilet, "Üslupsal Özellikleri Temelinde Tokat Gök Medrese’ye Yeniden Bakış", Zeitschrift für die Welt der Türken/Fournal of World of Turks, 7/2 (2015), ss. 243-260.

Konyalı, İbrahim Hakkı, Abideleri ve Kitabeleri ile Erzurum Tarihi, Ercan Matbaası, İstanbul 1960. , Abideleri ve Kitabeleri ile Konya Tarihi, Yeni Kitap Basımevi, Konya 1964. , Konya Tarihi, Haz. A. Candan-M. Temizyürek-Y. Candan, Memleket İletişim A.Ş. Yayınları, Konya 2007.

Kuban, Doğan. Selçuklu Çağında Anadolu Sanatı, Yapı Kredi Yayınları, İstanbul 2002. , Divriği Mucizesi (3.bs.), Yapı Kredi Yayınları, İstanbul 2003.

Kuran, Abdullah, "Tokat ve Niksar'da Yağı-Basan Medreseleri”, Vakıflar Dergisi, 7 (1968), ss. 39-43.

, Anadolu Medreseleri 1, Orta Doğu Teknik Üniversitesi Mimarlık Fakültesi Yayınları, Ankara 1969. , "Karamanlı Medreseleri”, Vakıflar Dergisi, 8 (1969), ss. 209-223.

Manaz, Abdullah, Suriye’nin Başkenti Şam’da Türk Dönemi Eserleri, Kültür Bakanlığı Yayınları, Ankara 1992.

Meinecke, M., "Tuslu Mimar Osman Oğlu Mehmed Oğlu Mehmed ve Konya'da 13. Üncü Yüzyılda Bir Çini Atölyesi”, Türk Etnoğrafya Dergisi, 11 (1968), ss. 81-93. Die Mamlukische Architektur in Ägypten und Syrien: (648/1250-923/1517 I, Abhandlungen des Deutschen Archäologischen Instituts, Kairo 1992. Die Mamlukische Architektur in Ägypten und Syrien: (648/1250-923/1517 II, Abhandlungen des Deutschen Archäologischen Instituts, Kairo 1992.

Numan, İbrahim, "Tokat Gök Medrese İle Yanındaki Yapı Bakiyesi Arasındaki Mimari Münasebet”, Suut Kemal Yetkin'e Armağan, Hacettepe Üniversitesi Yayınları Ankara 1984, ss. 249-261.

Odabaşı Zehra, "Celaleddin Karatay'ın Hayatı ve Siyasi Kariyeri”, Tarihçiliğe Adanmış Bir Ömür: Prof. Dr. Nejat Göyünç’e Armağam, Ed. H. Bahar, M. Toker, M. A. Hacıgökmen, H. G. Küçükbezci, Selçuk Üniversitesi Türkiyat Araştırmaları Enstitüsü Yayınları, Konya 2013, ss. 575-588. 
Ogan, Aziz, "Kayseri'de Hovand veya Mahperi Hatun Külliyesiyle Mimari Bakımdan Kıymet Taşıyan Kümbetler”, Türkiye Turing ve Otomobil Kurumu Belleteni, 167 (1955), ss. 3-4.

Önge, Yılmaz, "Emir Mübarezeddin Ertokuş'un Kümbeti ve Çinili Sandukası", Önasya, 3 (1967), ss. 14-15.

"Konya Ermenek'te Karamanoğlu Emir Musa Medresesi (Tol Medrese)", Önasya, 5 (1969), s. 51.

"Bugünkü Bilgilerimizin Işı̆̆ı Altında Divriği Ulu Camii ve Darüşşifası”, Divrĭgi Ulu Camï ve Darüsşifası, Derleyen, Yılmaz Önge-İbrahim Ateş-Sadi Bayram, Vakıflar Genel Müdürlüğü Yayınları, Ankara 1978, ss. 33-50.

Önkal, Hakkı. Anadolu Selçuklu Türbeleri, Atatürk Kültür Merkezi Yayınları, Ankara 1996.

Özbek, Yıldıray, "Women's Tombs in Kayseri/Kayseri'deki Kadın Türbeleri”, Kadın Araştırmalan Dergisi/fournal of Woman Studies, III/1 (2002), ss. 65-114.

Özkarcı, Mehmet, Afyon-Çay'da Ebû'l-Mücahid Yusuf Külliyesi, Kültür Bakanlı̆̆ı Yayınları, Ankara 1996.

Redford, Scott - Leiser Gary, Taşa Yazılan Zafer Antalya İçkale Surlarndaki Selçuklu Fetihnâmesi, Suna-İnan Kıraç Akdeniz Medeniyetleri Araştırma Enstitüsü Yayınları, Antalya 2008.

Rogers, J. M, "The Çifte Minare at Erzurum and the Gök Medrese at Sivas", Anatolian Studies, 15 (1965), ss. 64-85.

, "Mısır'ın Başşehri Kahire, IV. Mimari”, Türkiye Diyanet Vakfi İslam Ansiklopedisi, 24 (2001), ss. 182-191.

Sönmez, Zeki, Başlangıcından 16. Yüznıla Kadar Anadolu Türk-İslam Mimarisinde Sanatçlar, 1. Bs., Atatürk Kültür Merkezi Yayınları, Ankara 1989.

, Başlangıcondan 16. Yüzynla Kadar Anadolu Türk-Islam Mimarisinde Sanatçlar, 2. bs., Atatürk Kültür Merkezi Yayınları, Ankara 1995.

Sözen, Metin, Anadolu Medreseleri Selçuklu ve Beylikler Devri, I, Açık Medreseler, İstanbul Teknik Üniversitesi Mimarlık Fakültesi Yayınları, İstanbul 1970.

, Anadolu Medreseleri Selçuklu ve Beylikler Devri, II, Kapah Medreseler, İstanbul Teknik Üniversitesi Mimarlık Fakültesi Yayınları, İstanbul 1972.

Şaman Doğan, Nermin, "Isparta ve Çevresindeki Selçuklu-Beylikler Dönemi Yapılarında Devşirme Malzeme Kullanımı", Vakıflar Dergisi, 26 (1997), ss. 347354. 
"Selçuklu Döneminde Siyasi ve Bani Kimliği ile Mübarizeddin Ertokuş", Hacettepe Üniversitesi Edebiyat Fakültesi Dergisi, 27 / 1 (2010), ss. 231-251. , "Kayseri'deki Selçuklu Külliyeleri”, Hacettepe Üniversitesi Türkiyat Araştırmalan Dergisi, 16 (2012), ss. 191-214. , "Selçuklu Döneminden İki Sultanî Külliye (Kayseri Gevher Nesibe ve Sivas I. İzzeddin Keykavus Darüşşifaları)", Uluslararası Katılımlı XV. Ortaçăg ve Türk Dönemi Kazılan ve Sanat Tarihi Araştırmalan Sempozyumu, Anadolu Üniversitesi-Eskişehir, 2011, I, Anadolu Üniversitesi Yayınları, Eskişehir 2012, ss. 299-308.

(2013), ss. 15-26. "Kayseri'deki Selçuklu Dönemi Kadın Türbeleri”, Vakıflar Dergisi, 39 , Atabey Ertokuş Medresesi ve Türbesi, Bizim Büro Basımevi, Ankara 2013.

Şimşek, Ahmet, Cacabey ve Medresesi, Kırşehir Valiliği Yayınları, Kırşehir 2006.

Şükürov, Rüstem, "Harem Hıristiyanlığı: Anadolu Selçukluları’nın Bizans Kimliği”, Çev. Eda Havva Tan, Yay. Haz. İvan Pavli-Badegül Can Emir, Türk Bizans İlişkileri ve Anadolu'nun Türkleşme Süreci, Kültür Bilimleri Akademisi Yayınları, İstanbul 2016, ss. 135-163.

Taşkın, Saadet, "Anadolu Selçuklularında Çinili Lahitler", Sanat Tarihi Yillı̆̆ı, IV (1970-1971), ss. 237-257.

Temir, Ahmet, Kirşehir Emiri Caca Oğlu Nur El-Din’in 1272 Tarihli Arap̧̧a-Moğolca Vakfiyesi, Türk Tarih Kurumu Yayınları, .Ankara 1989.

Terzioğlu, Aslan, "Selçuklu Hastaneleri ve Avrupa Kültürüne Tesirleri”, Malazgirt Armağan, Türk Tarih Kurumu Yayınları, Ankara 1972, ss. 49-66.

Tuncer, Orhan Cezmi, “Sivas-Divriği Melîke Turan Şifahanesi’ndeki Türbe”, Divriği Ulu camii ve Darüş̧ifası, Derleyen. Yılmaz Önge-İbrahim Ateş-Sadi Bayram, Vakıflar Genel Müdürlüğü Yayınları, Ankara 1978, ss. 155-157.

, "Son Kazıların Işı̆̆ı Altında Sivas Şifahanesi Planı", I. Milletlerarası Türkoloji Kongresi, İstanbul, 15-20. X. 1973, Tebliğler, 3. Türk Sanatı Tarihi, Tercüman Gazetesi ve Türkiyat Enstitüsü Yayınları, İstanbul 1979, ss. 911-951. , Anadolu Kümbetleri I Selçuklu Dönemi, Güven Matbaası, Ankara 1986. , Anadolu Selçuklu Mimarisi ve Moğollar, (Yayınevi belirsiz), Ankara 1986. , Anadolu Kümbetleri 2 Beylikler ve Osmanl Dönemi, Sevinç Matbaası. Ankara 1991. 
Turan, Osman, "Selçuklu Devri Vakfiyeleri II Mübarizeddin Er-Tokuş ve Vakfiyesi”, Belleten, XI /43, (1947). 415-430.

"Selçuklu Devri Vakfiyeleri III. Celâleddin Karatay, Vakıfları ve Vakfiyeleri”, Belleten, XII/12, (1948), ss. 17-171.

- Selçuklular Zamaninda Türkiye Siyasî Tarih Alp Arslan'dan Osman Gâzi'ye (1071-1318), Ötüken Yayınları, 8.bs., İstanbul 2004.

Türkmen, Kerim, "Selçuklu Döneminde Kayseri’nin İmar Faaliyetine Katkıda Bulunan Hanımlar", II. Kayseri ve Yöresi Tarih Sempozyumu 16-17 Nisan 1998 Kayseri, Bildiriler, Erciyes Üniversitesi Yayınları, Kayseri 1998, ss. 437-449.

, "Kayseri Selçuklu Dönemi Yapılarında Yer Alan Ayet ve Hadisler",

Denktaş, Zafer Bayburtluoğlu Armağan, Sanat Yazılar, Ed. Mustafa Denktaş-Yıldıray

Özbek, Kayseri Büyükşehir Belediyesi Yayınları, Kayseri 2001, ss. 573-582.

Uluçam, Abdülselam, "Erzurum'daki Çifte Minareli Medrese Üzerine Yeni Bir Yorum", XI. Türk Tarh Kongresine Sunulan Bildiriler, II, (1994), ss.749-758.

, "Şam, IV. Mimari”, Türkiye Diyanet Vakfi İslam Ansiklopedisi, 38, (2010), ss. $320-325$.

Uyumaz, Emine, "Türkiye Selçuklu Sultanları, Melikleri ve Melikelerinin Evlilikleri”,

I. Uluslararası Selçuklu Kültür ve Medeniyeti Kongresi, 11-13 Ekim 2000, Bildiriler II, Selçuklu Araştırmaları Merkezi Yayınları, Konya 2001, ss. 397-421.

, Sultan I. Alâeddîn Keykubad Devri Türkiye Selçuklu Devleti Siyasî Tarihi (12201237), Türk Tarih Kurumu Yayınları, Ankara 2003.

, "Sultan I. Alaeddin Keykubad ve Zamanı", Anadolu Selçuklular ve

Beylikler Dönemi Uygarlĭg 1, Ed. Ahmet Yaşar Ocak, Kültür ve Turizm Bakanlığı Yayınları, Ankara 2006, ss. 107-115.

Ünal, Rahmi Hüseyin, Çifte Minareli Medrese (Erzurum), Kültür Bakanlığı Yayınları, Ankara 1989.

, Erzurum Yakutiye Medresesi, Kültür Bakanlığı Yayınları, Ankara 1992.

Yetkin, Suut Kemal, Çifte Minareli Medrese, Illahiyat Fakültesi Dergisi, II-III (1952), 4649.

Yetkin, Şerare, Anadolu'da Türk Çini Sanatını Gelişmesi, İstanbul Üniversitesi Edebiyat Fakültesi Yayınları (2. Baskı), İstanbul 1986.

Yinanç, Refet, "Sivas Abideleri ve Vakıfları (2)", Vakıflar Dergisi, 23(1994), ss. 5-18.

Yurdakul, Erol, "Kayseri Külük Camii ve Medresesinde Yapılan Hafriyat ve Araştırma Sonuçları”, Rölöve ve Restorasyon Dergisi, 1(1974), ss. 167-207. 

EKLER
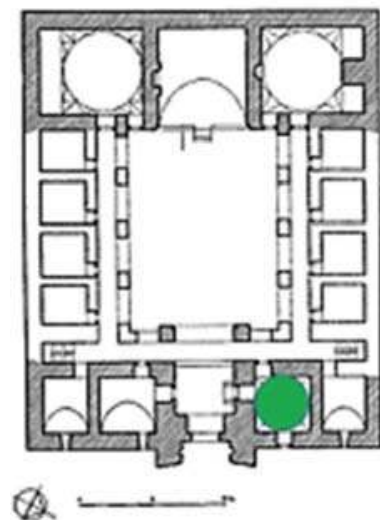

a
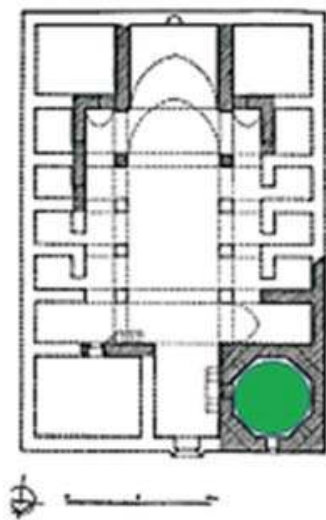

b

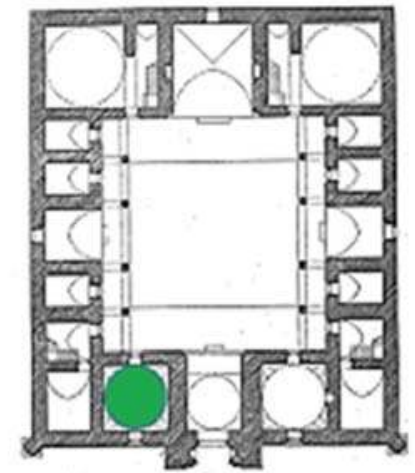

$-8$

c

Plan 1. a. Konya Sırçalı/Bedreddin Muslih Medresesi, b. Kayseri Avgunu Medresesi, c. Sivas Buruciye Medresesi (A. Kuran, 1969).

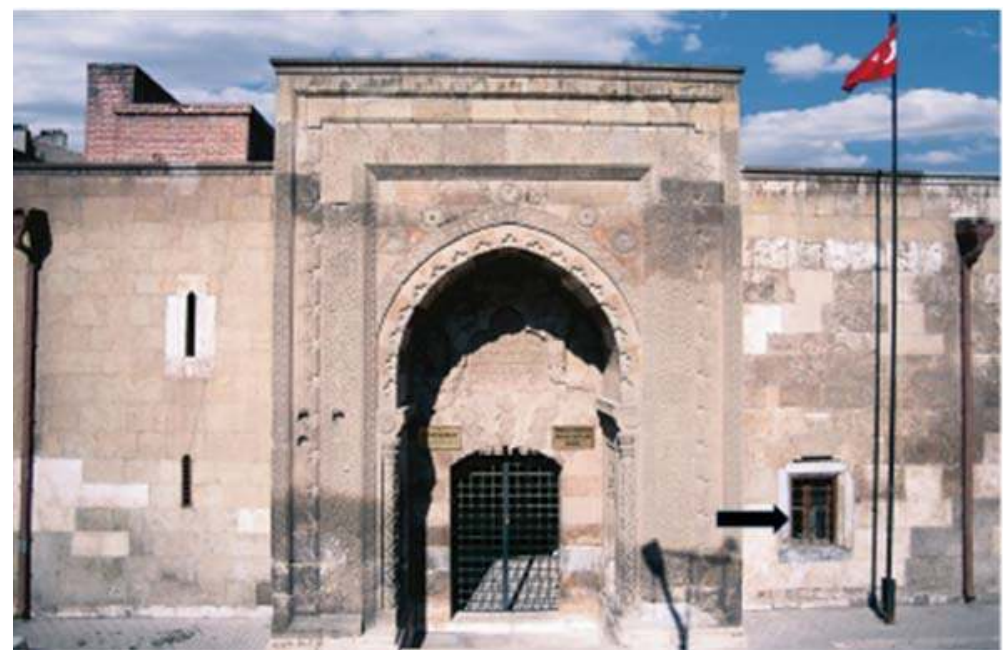

Fotoğraf 1. Konya Sırçalı/Bedreddin Muslih Medresesi, ön/doğu cephe. 


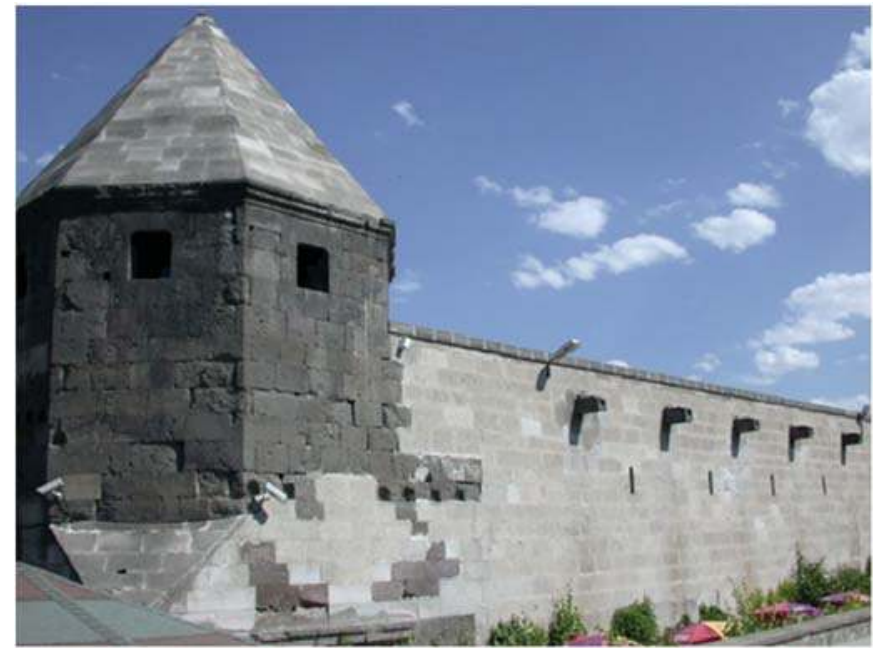

Fotoğraf 2. Kayseri Avgunu Medresesi, kuzeybatı köşe.

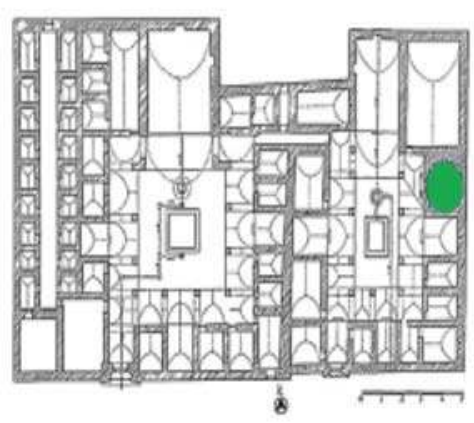

a

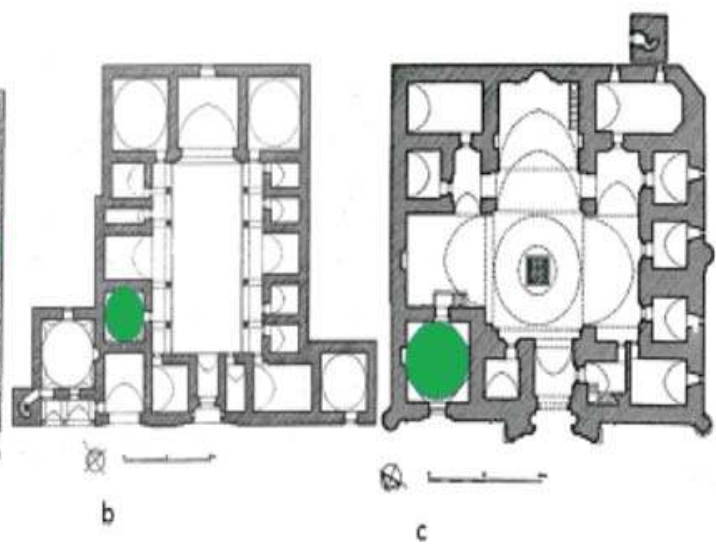

Plan 2. a. Kayseri Gevher Nesibe/Çifte Medrese (Vakıflar Genel Müdürlüğü Arşivi), b. Akşehir Taş Medrese, c. Kırşehir Caca Bey Medresesi (A. Kuran, 1969). 

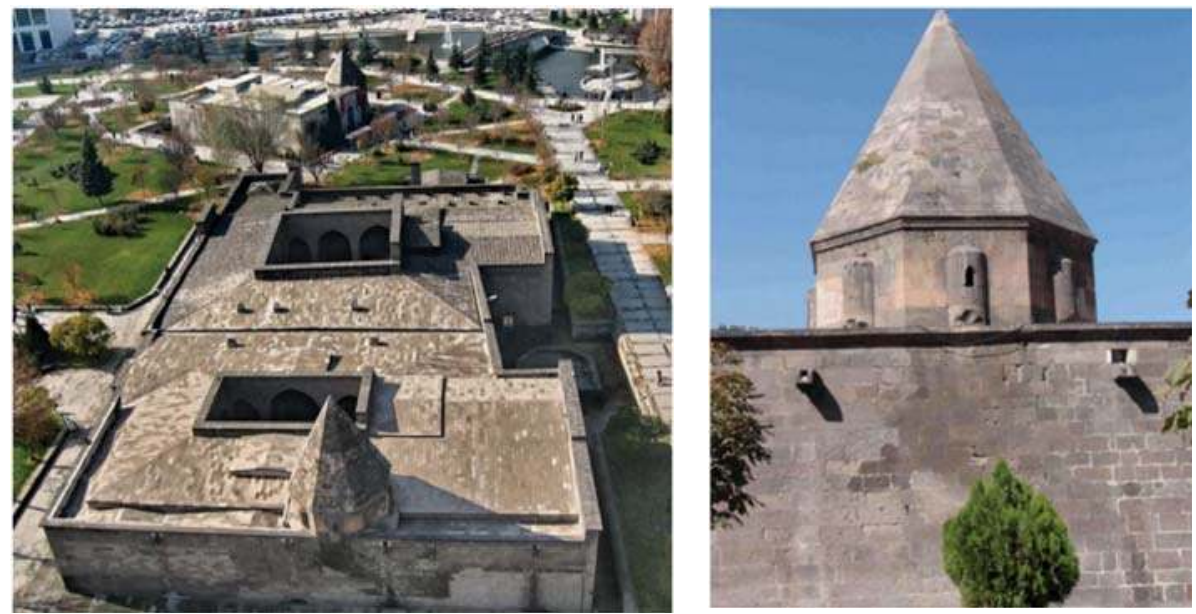

Fotoğraf 3. Kayseri Gevher Nesibe Darüşsifası-Medresesi-Türbesi.

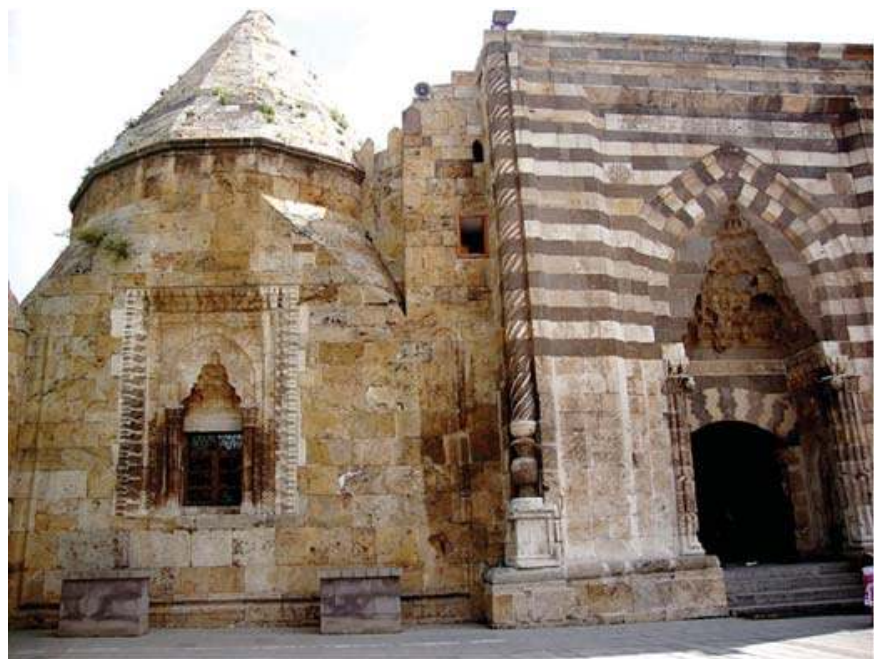

Fotoğraf 4. Kırşehir Caca Bey Medresesi ve Türbesi. 

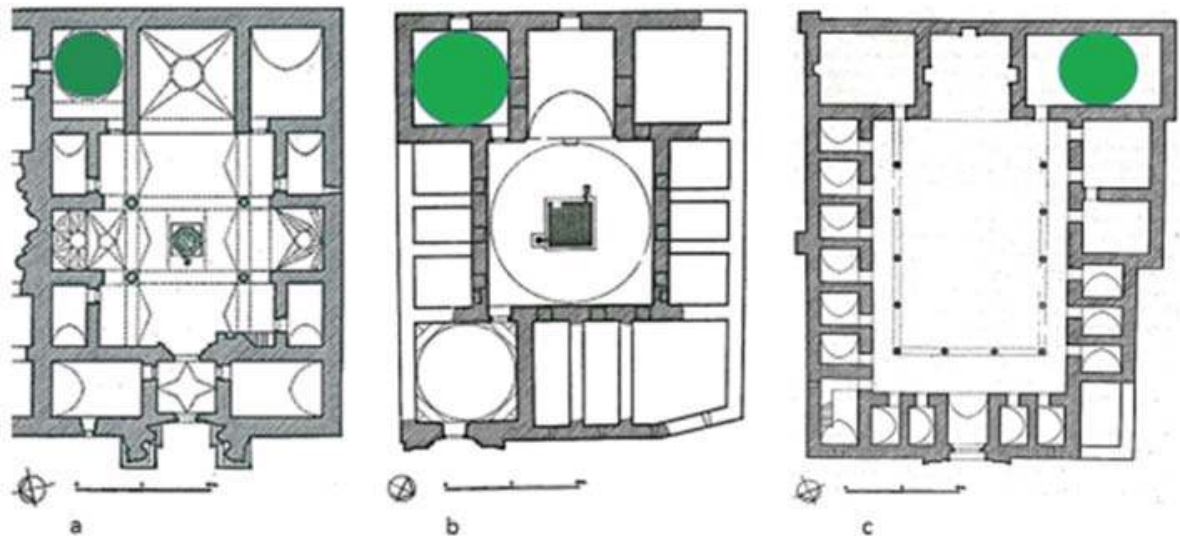

Plan 3. a. Divriği Ulu Camii Darüşşifası b. Konya Karatay Medresesi c. Tokat Gök Medrese, (A. Kuran, 1969).

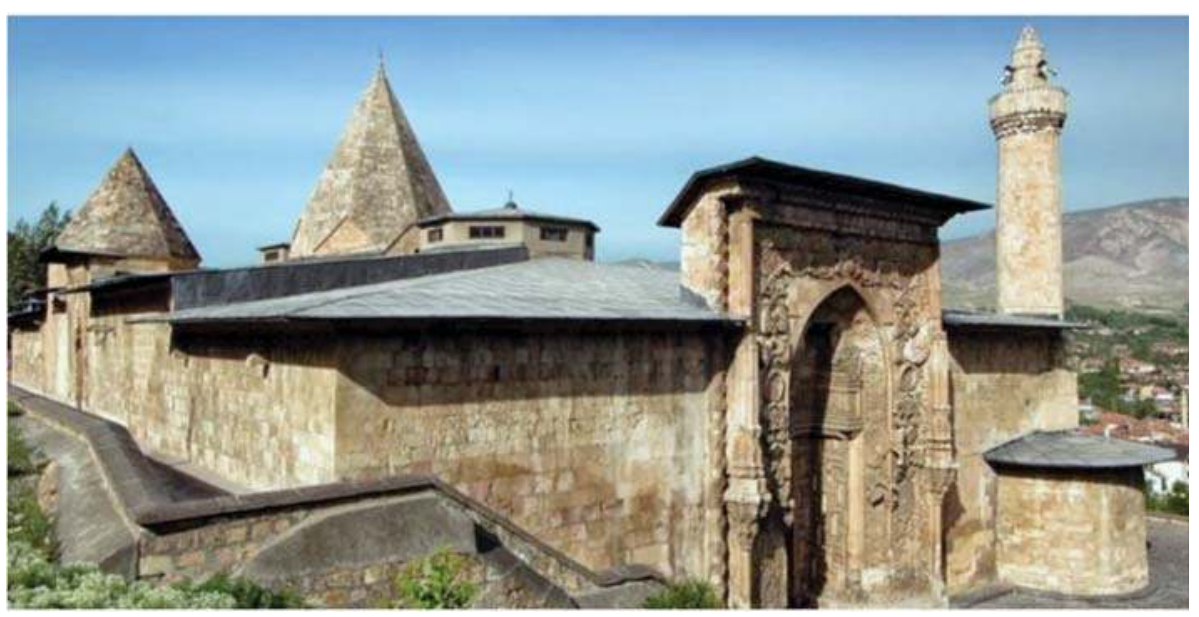

Fotoğraf 5. Divriği Ulu Camii Darüşşifası, kuzey ve doğu cepheden görünüm, Türbe. 


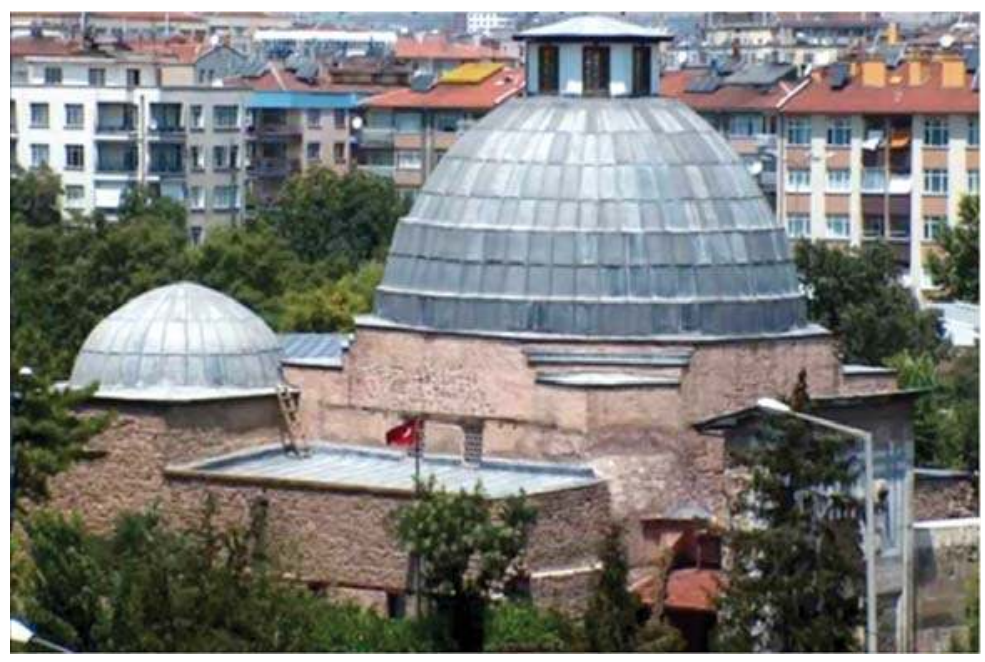

Fotoğraf 6. Konya Karatay Medresesi ve Türbesi.

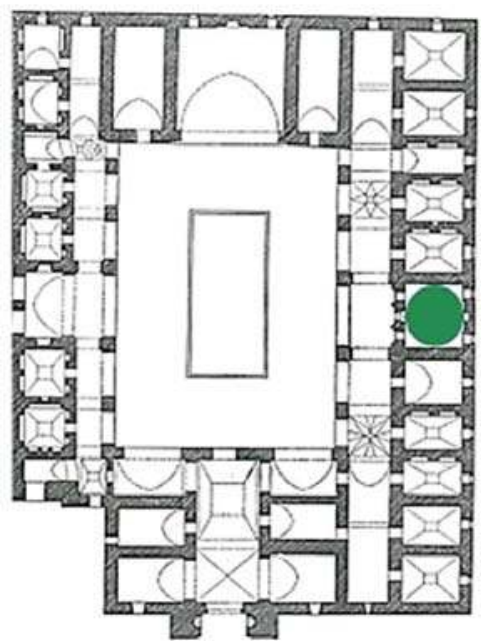

Plan 4. Sivas I. İzzeddin Keykavus Darüşşifası, plan (A. Kuran, 1969). 


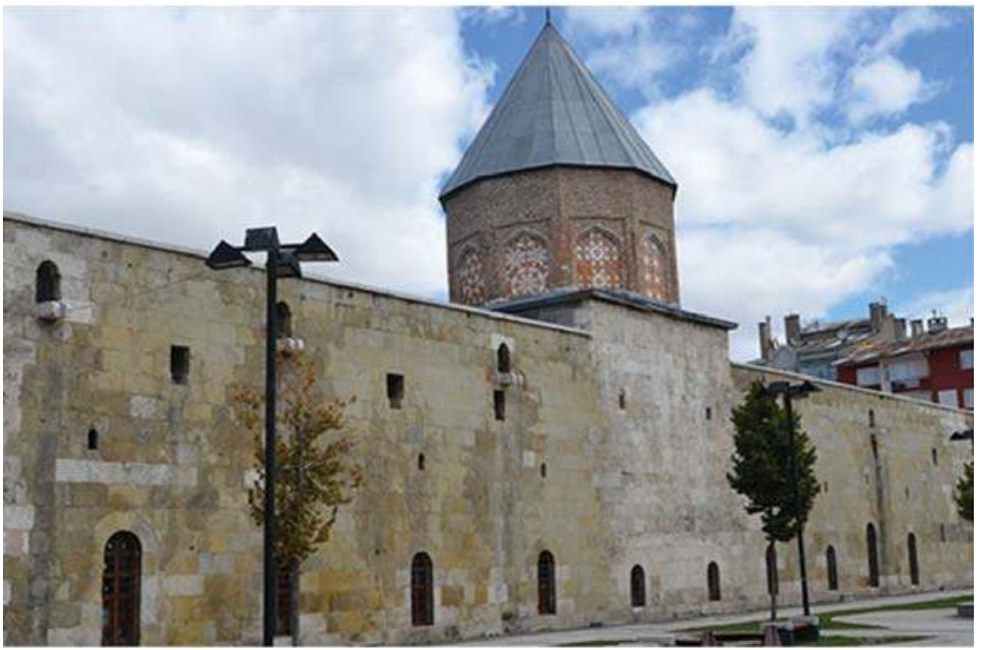

Fotoğraf 7. Sivas I. İzzeddin Keykavus Darüşşifası ve Türbesi.

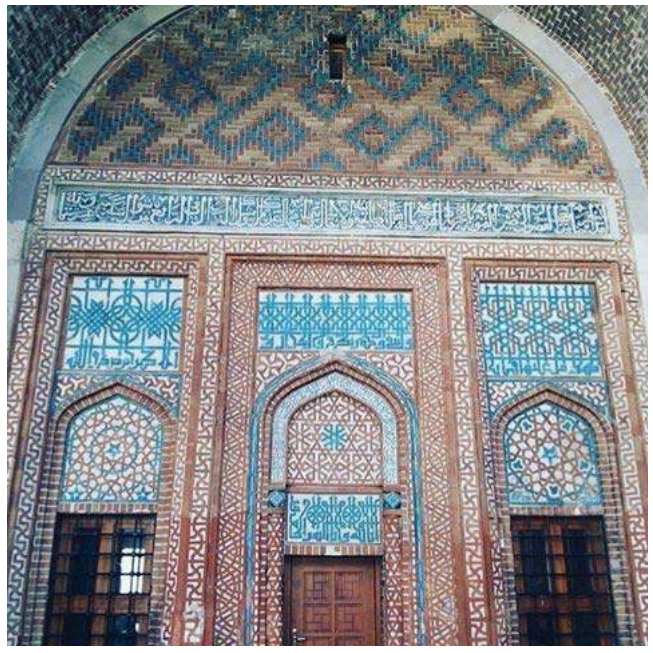

Fotoğraf 8. Sivas I. İzzeddin Keykavus Darüşşifası, kuzey cephe, kapı ve pencereler. 


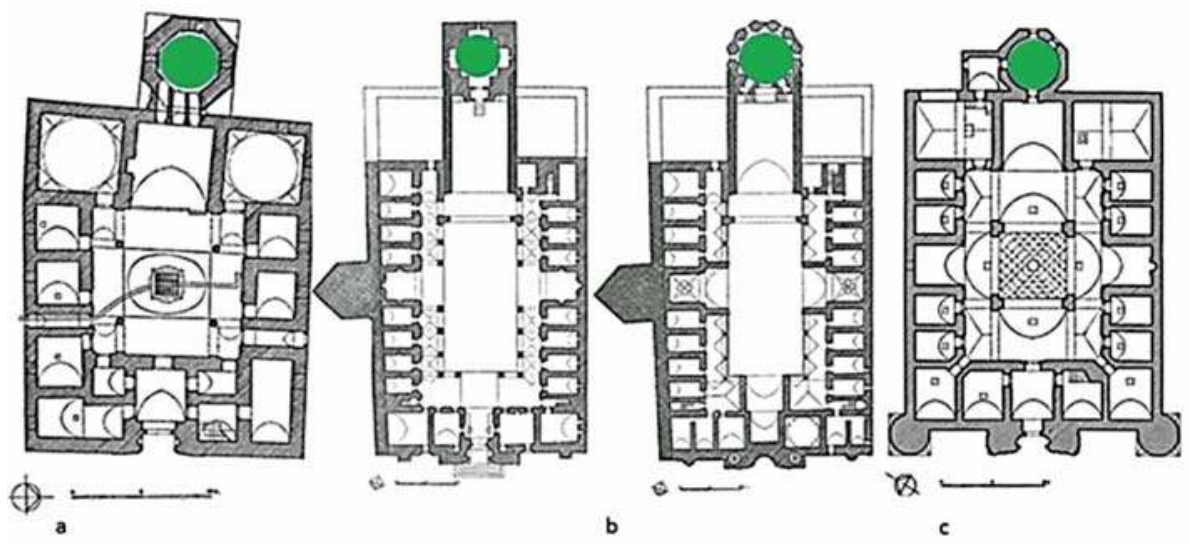

Plan 5. a. Atabey Ertokuş Medresesi, b. Erzurum Hatuniye/Çifte Minareli Medrese, c. Erzurum Yakutiye Medresesi (A. Kuran, 1969).

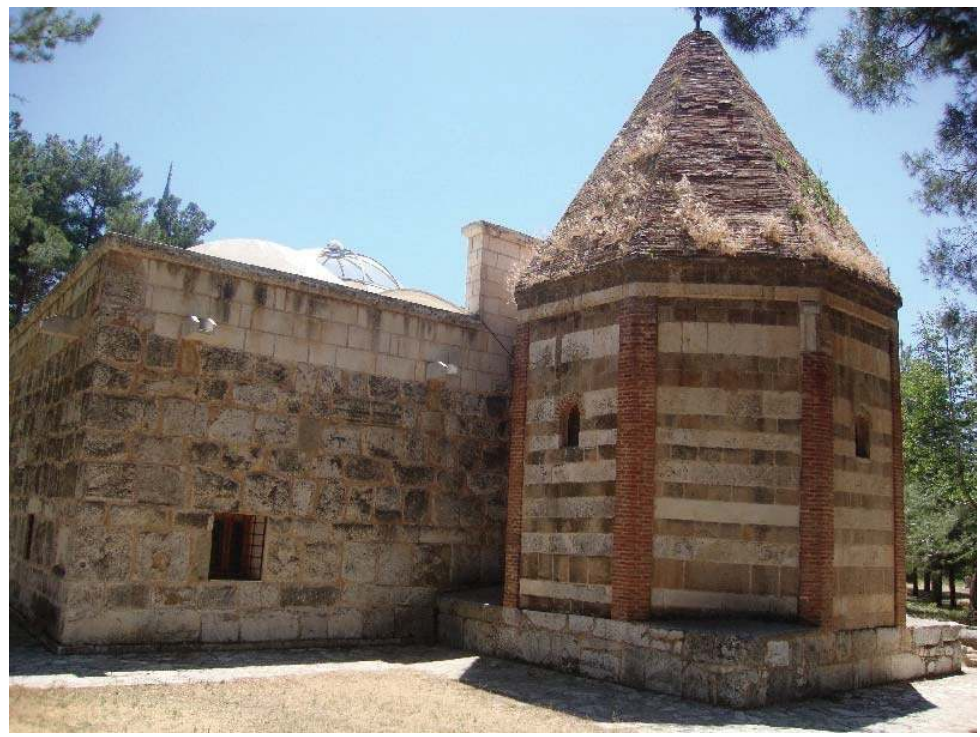

Fotoğraf 9. Atabey Ertokuş Medresesi, batı cephe, Türbe. 


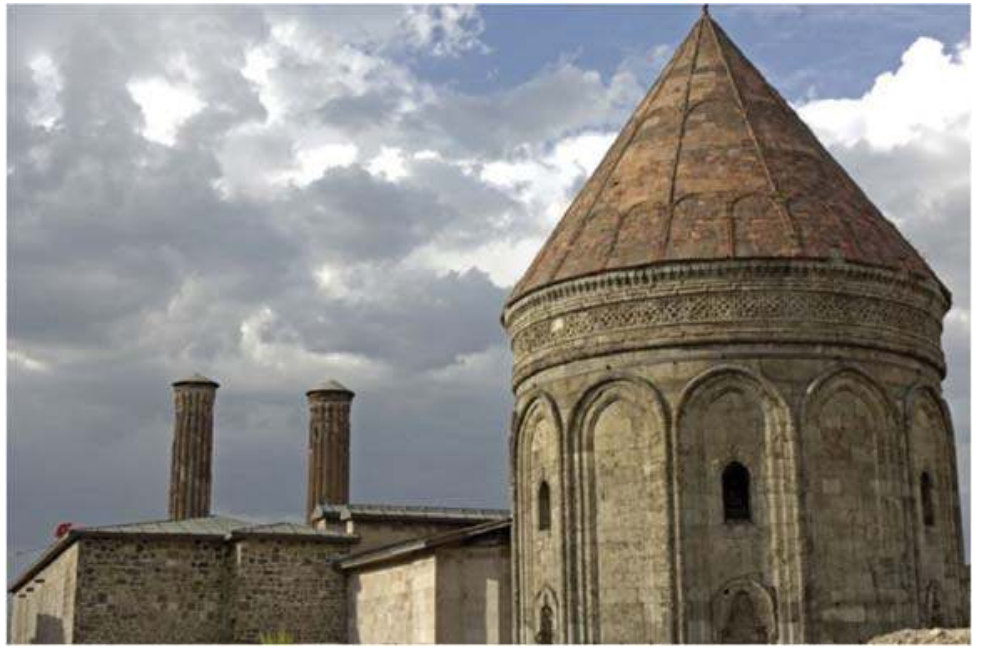

Fotoğraf 10. Erzurum Hatuniye/Çifte Minareli Medresesi ve Türbesi.

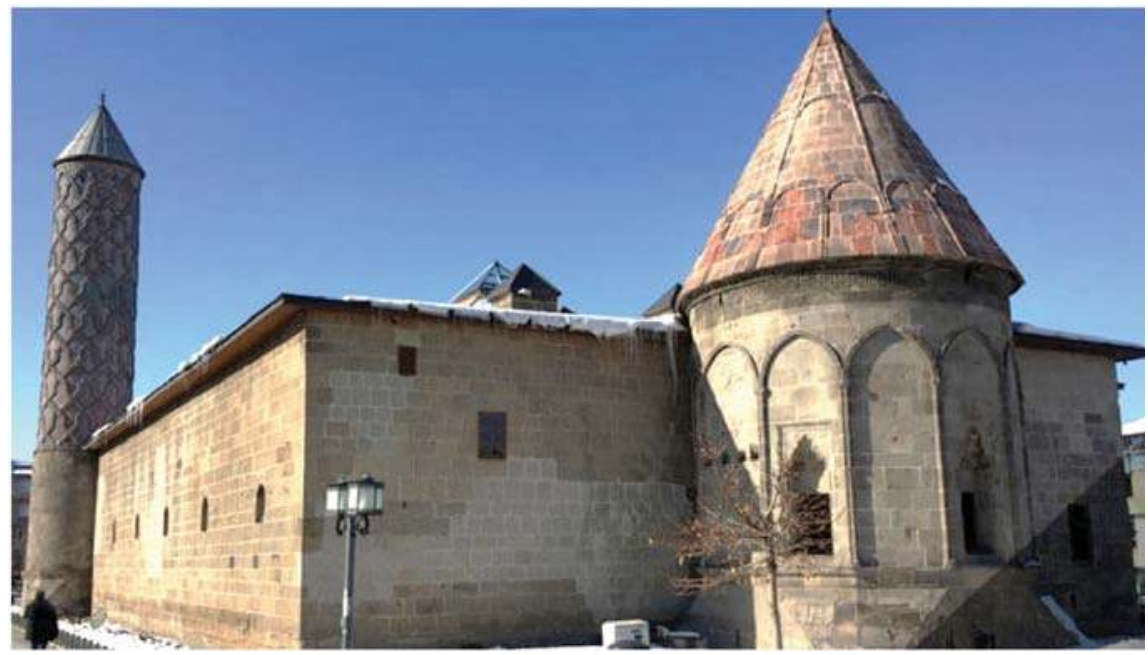

Fotoğraf 11. Erzurum Yakutiye Medresesi ve Türbesi. 

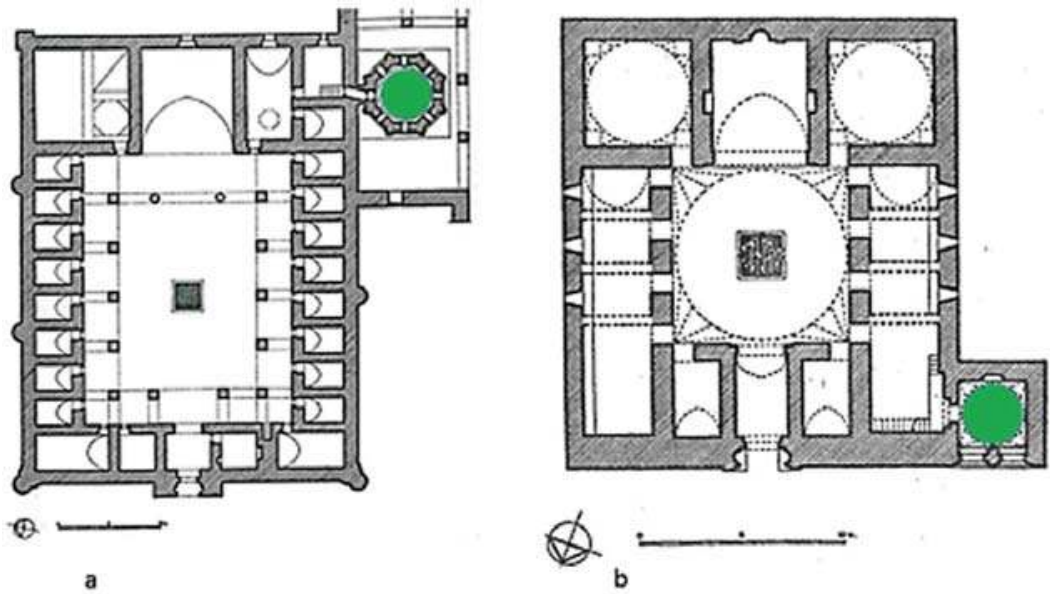

Plan 6. a. Kayseri Mahperi Huand Hatun Medresesi, b. Çay Taş/Yusuf Bin Yakub Medresesi (A. Kuran, 1969).
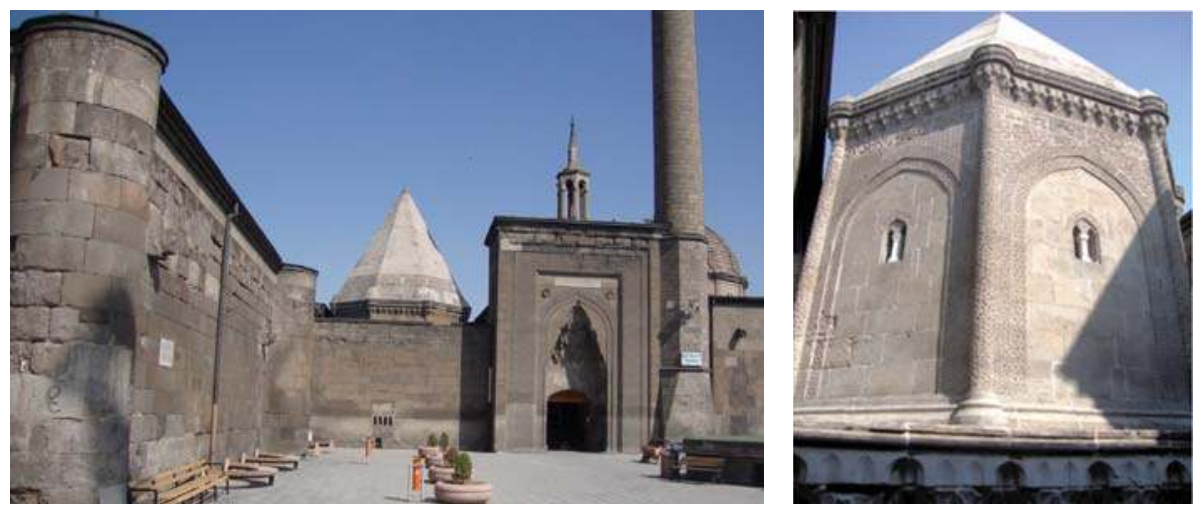

Fotoğraf 12. Kayseri Mahperi Huand Camii, Medresesi ve Türbesi. 


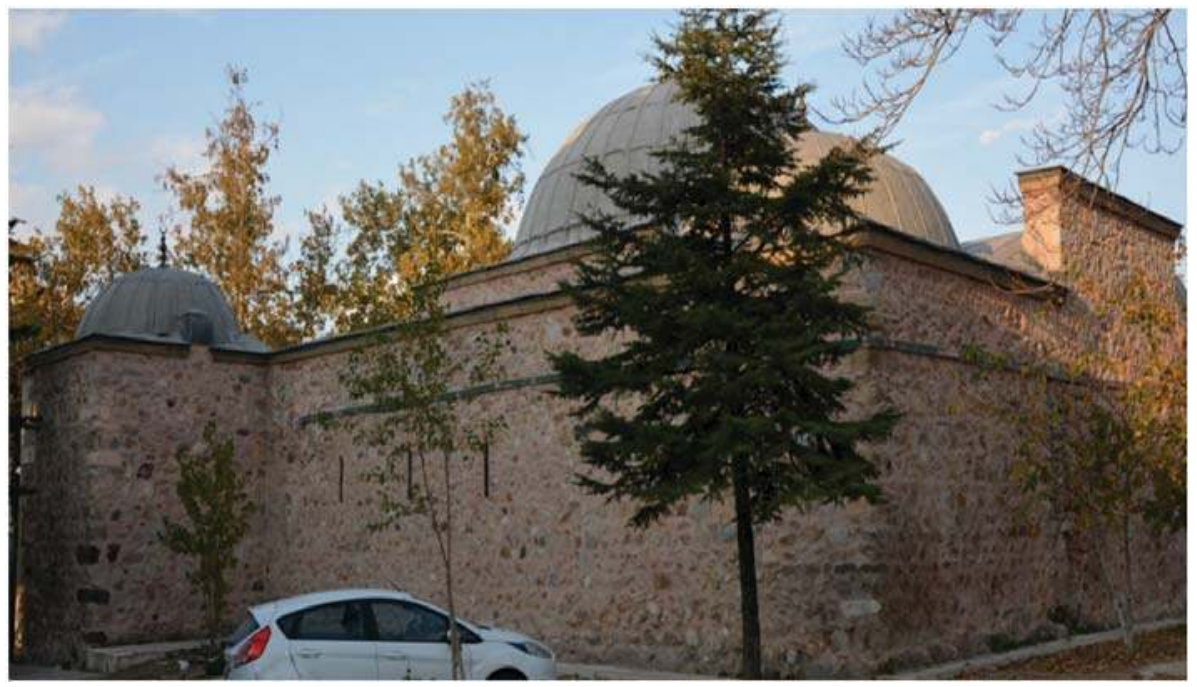

Fotoğraf 13. Çay Taş/Yusuf Bin Yakub Medresesi ve Türbesi.

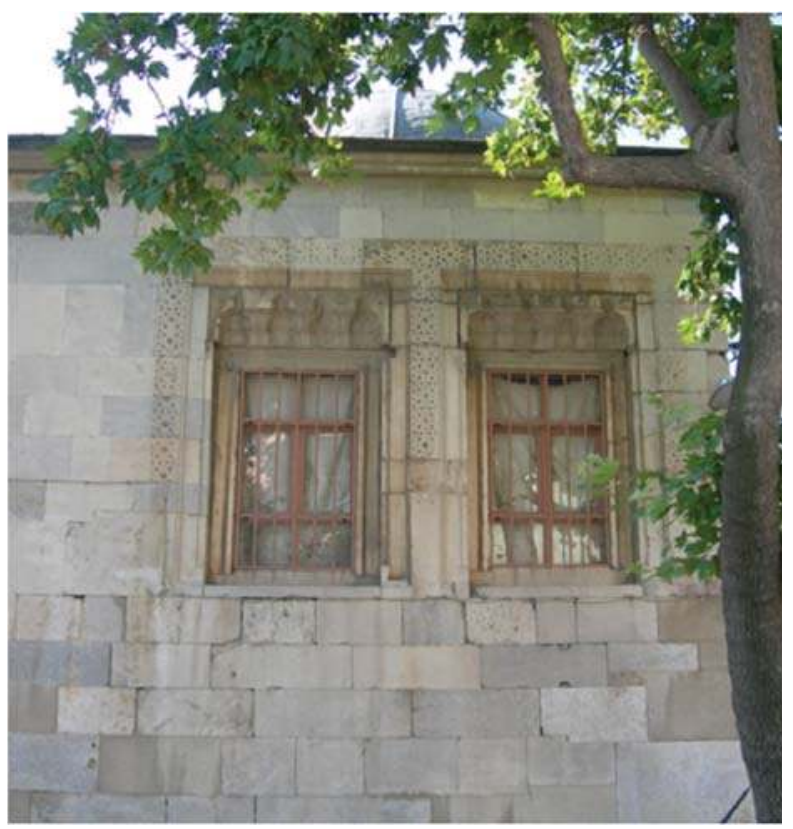

Fotoğraf 14. Çay Taş/Yusuf Bin Yakub Medresesi Türbesi, kuzey cephe, türbe pencereleri. 